\title{
The Spectrum of Religiousness, or What Makes an Object Religious. Habits, Patterned Evidence and Religious Meanings of Image-ObJects in PompeiI*
}

\author{
EL ESPECTRO DE LA RELIGIOSIDAD, O LO QUE CONVIERTE A UN OBJETO EN \\ RELIGIOSO. HÁBITOS, FUENTES QUE SIGUEN UN PATRÓN Y SIGNIFICADOS \\ RELigiosos DE LOS OBJETOS-IMAGEN EN POMPEYA
}

\author{
ANNA-Katharina Rieger \\ UNIVERSITY OF GRAZ \\ anna.rieger@uni-graz.at
}

\begin{abstract}
How do image-objects obtain a religious meaning? When can we interpret material evidence as traces of a religious ritual? These questions are central to the archaeology of religion, but often answered in favor of religion without sound criteria. Using examples from Pompeii I look into "material religion" through the lens of viewing
\end{abstract}

\begin{abstract}
RESUMEN
¿Cómo adquieren los objetos-imagen un significado religioso? ¿Cuándo podemos interpretar las fuentes materiales como restos de un ritual religioso? Estas cuestiones son fundamentales para la arqueología de la religión, pero a menudo se responden en favor de lo religioso sin criterios sólidos. Utilizando ejemplos de Pompeya, exploro en
\end{abstract}

\footnotetext{
* This contribution is an attempt to study the complexity of Roman material religion and to connect it with ritual studies and social habitus with still many blurs, flaws and gaps in the present text. Nevertheless, I am convinced that the approach is promising. The arguments gained much from the substantial and enlightening remarks by the two anonymous reviewers. I could present some of the ideas about Pompeii and religion at the conference of the DVRW in Hannover, where Christa Frateantonio, Verena Fugger, and Jörg Rüpke commented on it, and in a colloquium at Graz, where David Palme, Luca Pellarin, Elisabeth Trinkl and Peter Scherrer raised helpful questions and gave advice. Elisabeth Begemann improved my idiosyncratic English. All errors and short-comes are mine.
} 
habits and habitualized practices embedded in and shaping social and cultural habitus in a Roman city of the $1^{\text {st }}$ cent. CE. This practice-oriented approach to religion and material culture allows for a more nuanced interpretation of when and how people in Graeco-Roman antiquity conceived of an image-object as religious and ascribed a religious meaning to it. Based on an understanding of religion as communication with supra-human agents, the notion of a "spectrum of religiousness" softens the black-and-white view on motifs and objects as either religious or profane. The distinction of a gradually varying perception of image-objects is archaeologically based on both loosely assembled evidence (e.g. the iconographical and material remains in a house) or intentionally arranged evidence (e.g. niches with altars in front of them). In the repetition of such material reflections of practices the religious character of imageobjects comes to the fore. este estudio la "religión material" a través del prisma de los hábitos de visión y de las prácticas habitualizadas que están imbricadas en, y que a su vez moldean el habitus social y cultural de una ciudad romana del siglo I d.C. Este enfoque de la religión y de la cultura material centrado en la práctica permite una interpretación más precisa de cuándo y cómo las personas en la Antigüedad grecorromana concebían un objeto-imagen como religioso y le adscribían un significado religioso. Basado en la idea de religión como comunicación con agentes suprahumanos, la noción de "espectro de religiosidad" suaviza la visión en blanco y negro de los motivos y de los objetos como religiosos o profanos. La distinción de una percepción gradualmente variante de los objetos-imagen esta fundamentada arqueológicamente, tanto en los materiales que aparecen reunidos de manera indirecta o casual (ej. los vestigios iconográficos y materiales de una casa), como en aquellos que fueron deliberadamente organizados (ej. nichos con altares en frente de ellos). En la repetición de estos reflejos materiales de las prácticas se aprecia el carácter religioso de los objetos-imagen.

\section{KEYWORDS}

Egyptianizing Dwarf; Material Religion; Nudity; Social Habitus; Viewing Habits.

\section{PALABRAS Clave}

Desnudez; enano egiptianizante; hábitos de visión; habitus social; religión material. 


\section{OMnipresent, Mute OR INDifferent. Deities RePresenting Religion in PompeiI}

It was a natural disaster of unprecedented measure, when the eruption of Mount Vesuvius in summer $79 \mathrm{CE}$ destroyed many urban and rural settlements, killed the inhabitants that had not sought their salvation in flight, and covered buildings, fields, gardens and the entire infrastructure in the Sarno plain and along the Golf of Naples with ashes and lava. Pliny the Younger, who allegedly had a Stoic background, describes the eruption as a moment of complete absence of the gods. ${ }^{1}$ In order to cope not only with such dramatic situations, but also minor contingencies in their lives, people rely on (what we call) religion, which played an important role (not only) in Graeco-Roman antiquity. As an irony of fate, the moment of the absence of the gods resulting in the ancients' perception in the total extinction of Pompeii is the reason why today we can study where and how deities were active, and how Pompeians made them parts of their lives. It goes without saying that the Campanian city with its phases of archaic Samnite harbour to Roman republican colony to early Imperial city offers rich evidence of the urban grid, of architecture, religious buildings, sculpture, paintings, epigraphical documents and all kind of objects from various materials (glass, metal, terracotta, stone), from which archaeology can reconstruct the societal groups, the political and administrative organization, the infrastructure, resource provisions, economic production and exchange. In all these areas of the

1. Plin., Ep. VI 20, 15. See Jones, 2001. For an overview of the history of not only this catastrophe in the region of the Gulf of Naples and the Sarno plain see Meller and Dickmann, 2011.

ARYS, 18, 2020 [51-94] ISSN 1575-166X 
city's life people included communication with super-human agents. ${ }^{2}$ Based on material from mainly the early Principate, when the city was struck by the catastrophe, but also from the earlier phases of Republican times inquiries are possible into how people established relations to the deities in such a community and place. How did they do this in order to avert complications and crises - either personal or communal ones? What forms of religious activities did they adhere to, agree or disagree on, or participate in? And what material objects and image-objects where involved?

The backdrop to the questions about religion in Pompeii and the spectrum of religiousness that is manifest in image-objects, is the ubiquity of imagery, objects, and buildings that refer to deities, cult practices, or mythological representations (in either images or texts) where the gods often play an important role. The ubiquity results in flaws when it comes to archaeologically explain why or in how far exactly something is religious or what creates a "sacred atmosphere".

This neglects the analysis of what characteristics of a painting, image-object or architectural space and their contexts indicate their potential religiousness, ${ }^{4}$ since they are often studied for the sake of the iconographical motifs and their origins, or the stylistic and chronological development. What needs to be illuminated is how exactly the religious meaning of the various pieces of evidence can be determined in archaeology, based on the question of how the individual related to these objects. This is at the core of material religion. ${ }^{5}$

With two case studies from Roman Pompeii, I attempt to add to a more dynamic understanding of religion in the studies of material culture from the Ancient Mediterranean. ${ }^{6}$ Drawing on the image-objects of statues of nude men and dwarfs

2. For a brief introduction to the history and archaeology of Pompeii see Zanker, 1995 and Dickmann, 2005. Religion in Pompeii is the topic of the monograph by Van Andringa, 2009, that analyzes the evidence for religion in the different areas of life and activities in the Vesuvian cities.

3. E.g. Bowe, 2009 and Neudecker, 2015, p. 227. See below par. 2.2. and 3.1. Despite the approaches to atmospheres created by decorative schemes in rooms or in sensory perception of cities (Haug, 2014 and 2017, referring to Böhme, 1995), more has to be done for a general understanding and use of "atmosphere" in the archaeology of religion by combining aesthetic with spatial theories and looking for the micro-strategies of individuals. For exemplary approach in modern contexts see Hasse, 2008.

4. The term "image-object" takes into account the material and iconographic aspects of two- and three-dimensional evidence, which includes the material aspect in iconographic analysis and allows for applying iconographic methods for material objects, see for a first application Rieger, 2018.

5. For situational meaning of objects see Raja and Weiss, 2015 and 2016. For general approaches on material in ancient religions or religious studies see Boivin, 2009; Insoll, 2009; Elsner, 2012; Barrett (C.E.), 2016; Bräunlein, 2016; Moser and Knust, 2017. The volume edited by Mylonopoulos, 2020 (not yet published) will also focus on the role of image-objects in religion. See nn. 8 and 9 on ritual.

6. Whitehouse, 1996; Insoll, 2004b and 2011b. See n. 5.

ARYS, 18, 2020 [51-94] ISSN 1575-166X 
that are often related to religious representations or atmospheres, I argue that a look at the material evidence that considers iconographical and behavioral triggers as well as the spatial contexts of the urban fabric of Pompeii allows for distinguishing gradually different expressions of religion and religious practices.

Assemblages as non-patterned and arrangements as patterned and repeatedly found forms of evidence allow for reconstructing such practices. ${ }^{7}$ Repeated practices are the foundation for what can become rituals; when supra-human agents are involved these rituals become religious. In the same vein, I claim that image-objects can gain "religiousness" by being involved in such practices.

To add to an understanding of the specificity of rituals as religious practices I will set them into relation with routines and habits as well as social habitus, which I turn to at the end. ${ }^{8}$ This approach results in a break-up of rituals and religion as static concepts, since I relate them to repeatedly enacted habits grounded in daily-life and environments. Acknowledging ritualization ${ }^{9}$ of practices and gradually changing religiousness of involved image-objects, people and spaces helps overcome the binary way of interpreting them as either religious or profane. ${ }^{10}$

7. On the differentiation of assemblage and arrangement and the significance of patterns and repetitions for the reconstruction of religious practices see infra pp. 59-61; 74-76.

8. On the relation of habit, habitus and ritual see infra pp. 74-78. I draw on the recent definition of ritual by Kyriakidis, 2007, pp. 290-293 and n. 1, arguing in favour of a gradual differentiation of institutionalized practices, since not all formalized repeated activities become rituals. For the basic decipherments of rituals and ritualisation in anthropology see Bell, 1992 and Rappaport, 1999, esp. the latter with a structuralist approach. For a practice-oriented approach see Fogelin, 2007, p. 65, who describes the two ways archaeology tends to look at religious rituals (symbolism or human action), to which add the archaeological positions of Elsner, 2012; Rowan, 2012; Swenson, 2015. In German speaking academia the definiton of ritual by Stollberg-Rilinger, 2013, p. 9 ("Standardisierung der äußeren Form, Wiederholung, Aufführungscharakter, Performativität und Symbolizität gekennzeichnet ist und eine elementare sozial strukturbildende Wirkung") is influential, who stresses the performative character of rituals. However, many of the mentioned authors are interested in rituals that concern and involve larger numbers of individuals and have transformative and identity-establishing purposes (see Michaels, 2016 on the latter aspects). From the perspective of a dynamic understanding of materiality there is still more to investigate about rituals.

9. For the process and significance of ritualization see Bell, 1992, p. 74: "ritualization is a way of acting that is designed and orchestrated to distinguish and privilege what is being done in comparison to other, usually more quotidian, activities". In this process one should integrate the option of dissolving the ritualised situation and involved agents afterwards (ephemerality).

10. On sacralization see Anttonen, 2005; Schlette and Krech, 2018. For Graeco-Roman religion see Rüpke, 2020 on ritual objects; Rieger, 2018 and 2020b on situationally limited "sacralized spaces". Barrett (C.E.), 2019 dedicated her study of objects and contexts from Pompeii to the shifting meanings of Egyptianizing objects with a focus on identity in a cosmopolitical empire. Her claim is to dissolve the "oppositions of 'religious' versus 'decorative' imagery" in order to allow for the "multiplicity of func-

ARYS, 18, 2020 [51-94] ISSN 1575-166x 
The dynamic view on religion is based in the paradigm of Lived Ancient Religion that accounts for the deviations, transformations, omissions or additions that occur in religious practices and is reflected in the material evidence. Applied to rituals, axiomatic assumptions of archaeology have to be re-thought. ${ }^{11}$ Even highly repetitive, scripted, recognizable, symbolically invested practices - rituals - are subject to the appropriating, dynamic and situational capacities of the involved agents and performative moments. ${ }^{12}$ As with the too rigid labels of religious or non-religious, rituals also can be less complex and grounded in ordinary habits. These habits, habitual knowledge and the ritualization of habits as well as their relation to social habitus are in a constant flow and bring to bear on image-objects and how agents engage with them.

Questions about the religious meaning of image-objects and spaces are not only of interest for a certain period in the particular socio-cultural and historical situation of Pompeii. A detailed analysis of the ways of how people established relations to deities in a given social and material environment can be used as a model for understanding the position of ancient Roman, or other polytheistic religions. Rituals are social institutions (and can involve many people) as well as individual practice. ${ }^{13}$ This entails tensions and potentials for the creation or creative adaptations of rituals, and religion as a field of social discourse and the production and employment of media. ${ }^{14}$

\section{To Unmute the Evidence. Material Practices, Religious Communication and People}

In the city of Pompeii the environment in which individuals or groups establish relations to the deities is in spatial and material regards the urban fabric of - at the moment of the destruction - a Roman-Campanian city of the $1^{\text {st }}$ cent. CE. This environment impacts how human agents relate to each other, or to image-objects; it

tions, values, and significations" (pp. 16; 103; 303-312; 337) in such imagery. This builds on strands in Classics that started with studies such as Bremmer, 1998 or Elsner, 2012, esp. pp. 10-11. See recently Adrych and Dalglish, 2020 with a review on the perception and study of objects in the archaeology (of religion), while Moser and Knust, 2017 do not tackle this problem in depth.

11. Rüpke, 2011; Albrecht et al., 2018. For the applications of the LAR-paradigm in archaeological material see Raja and Rüpke, 2015b; Raja and Weiss, 2016; Gasparini, 2020; Rieger, 2020b.

12. See supra p. 55 and nn. 8-9 on ritual and ritual theory.

13. The tension between and foundations of an individual's behaviour (agency) and a community's values, beliefs, and norms (structure) and vice versa is partly resolved by the Bourdieuan concept of habitus (Bourdieu, 1977 and 1979), as well as Giddens structuration theory (Giddens, 1984), further developed in practice-theoretical approaches for archaeology. See Antczak and Beaudry, 2019.

14. Meyer, 2003. 
influences the ways of doing religion and affects the different social habitus. ${ }^{15}$ With a praxeological approach, archaeology opens ways to take into account considerations of everyday activities of human agents on the basis of material objects for a perspective on religion. ${ }^{16}$

\subsection{Material Religion and the Concepts of Religious Communication, Agency and Ritual}

In order to bring material evidence to bear on the reconstruction of past religious practices, I conceive of religion as a human resource that 1 ) ascribes agency to some "counterintuitive agent" and 2) enlarges the agency of human beings (thus enabling them to cope with various situations). To influence or get closer to the agency of these beings, 3) communication is necessary, hence religion enables and improves communication in various directions and with various addressees. ${ }^{17}$

The understanding of religion as communication of different agents enables archaeology to usefully focus on the media of such communication - image-objects, motifs and their material, inscriptions, the spatial environment - that are more or less strategically involved establishing relations to the deities. ${ }^{18}$ Communication in this context goes beyond a semiotic conception of a message send with a certain meaning to be received and understood by an addressee. This falls short of explaining the variations, complexity and transformations of historical and archaeological sources. Religious communication is inevitably historically contingent and contextually embedded as well as individually experienced. As part of a past society's organization, religious communication also depends on individual predispositions (informed by experiences, knowledge, habits, social habitus, expectations etc.) and

15. It is not the scope of the paper to discuss these terms with all their sociological or cultural-anthropological implications and critique, but give the background to how I can operationalize them for archaeological image-objects in Pompeii and the reconstruction of religious practices; see Knapp and van Dommelen, 2008 on how habitus influences habits, however one should widen it to a mutual influence. See infra pp. 74-78.

16. Schatzki, Knorr-Cetina and Savigny, 2000; Reckwitz, 2012 and 2016 for focussing the attention on individuals, embodiment and practices. For applications in archaeology and history see Pauketat, 2001; Cipolla, 2014, who emphasized the embodied, spatial and material dimensions of practices.

17. See Rüpke, 2018, pp. 69-70, however I leave out the aspect of identity, Rüpke's third category.

18. See von Hesberg, 2007 for an application of a communication theory for the analysis of archaeological material with religious meanings. Epigraphically, inscriptions on image-objects mentioning ex voto, ex iussu, or an altar, as well as sacrificial remains are the clearest clues for a highly repetitive religious communication.

ARYS, 18, 2020 [51-94] ISSN 1575-166x 
leads to modifications, adaptations and variations of what could be transmitted, received or understood. ${ }^{19}$ In a semiotic perspective, the archaeological material mirrors potential addressees, receivers and messages, but in a relational perspective, it adds to the communicative frame of religious practices, and how visual and material triggers may have impacted people - apart from an intended meaning. ${ }^{20}$ From the material sources, we infer communicational habits with a set of image-objects, or repeatedly conducted practices, that reflect also (social) habitus. Especially the latter is bound to or based on horizons of expectations and horizons of experiences of the individuals of a society or societal groups. ${ }^{21}$

Individuals and a society like the one in Pompeii tested which kind of communication with the deities was successful by their repeated but modified actions. Sometimes partial, sometimes imperfect performances and appropriations of movements, gestures, and motifs render religion and religious communication "elastic". People performed or uttered prayers differently each time, motifs such as a Venus were painted, stamped or sculpted differently. Various strategies to negotiate and adjust rituals and habits are a continuous source for religious innovation and change.

Emphasizing the "lived" aspects of religion entails accepting the agency of objects and their situational meaning. Agency of human and non-human agents (things, people, animals, environment) describes their capacity to be or enter in relations to something or someone else. Humans can "act", while an object can only enact agency in relation to other things, humans etc. ${ }^{22}$ Bringing agency to bear on

19. This focus on the re-shaping, re-negotiating and re-appropriating religious traditions, hence on the creativity and transformative capacities of religion, lies at the heart of the "Lived Ancient Religion" paradigm: see for applications Gasparini et al., 2020 and for the approach Rüpke, 2011; Raja and Rüpke, 2015b; Albrecht et al., 2018, where, however, ritual does not take center stage. Habits are understood as repeated schemes of actions by members of a group (community of the Pompeians) that rely on shared values, ideas, and belief. Habitual practices are reflected in the material-archaeological pattern. See Michaels, 2016 and infra pp. 59-62; 74-76.

20. For visual triggers in the urban fabric of Pompeii, see Rieger (forthcoming a).

21. For religious experiences see e.g. Patzelt, 2018 for praying; studies of the variations of image-objects and their perception see Stewart, 2003; Lorenz, 2005 and 2016; Trimble and Elsner, 2006; Brain, 2018.

22. See in general on agency in archaeology Dobres and Robb, 2000; Gosden, 2005; Joyce and Lopiparo, 2005. Barrett (J.C.), 2001 emphasizes more specifically the agency in "structured material conditions". The sociological and art historical basis for approaches to agency is Gell, 1998 based on e.g. Latour, 2005 and earlier studies from economic sociology; for agency in religious practices Alvar Ezquerra, 2018; Rieger, 2016, esp. pp. 309-310 on agency of objects in sacred contexts; Rieger (forthcoming b) for the agency of landscape playing a role in establishing religious institutions; Stewart, 2007 for agency of images. For applications to material objects in Pompeii, especially Egyptianizing material, see Barrett 
the history of religion or on ritual theories means that the qualities of interactions (of objects, people, spaces) in a social environment and with agents beyond this environment (deities, ancestors, divinized natural phenomena), and the ways of possible communications become more variegated. Moreover, it leads to revealing their situationally ascribed meanings.

\subsection{When is it Religious? Assemblages, Arrangements and Repeated Patterns of Material Evidence and the Reconstruction of Practices}

The methodological instrument of archaeology to reconstruct possible agentive relations of (image-)objects lies in taking seriously the various contexts an object is embedded in. The first-hand context is its findspot (e.g. a street corner in Pompeii) and the archaeological conditions of material category and preservation (e.g. a coin with a still discernible image). They determine a first archaeological approach to the usage and meaning of objects (in the hand of the people of Pompeii in a particular period, seeing certain images). The second level of context of an image-object reveals clues to relations established by form, motif and iconography (in case of the coin, e.g. what kind of seal, what tradition in the iconography), material (what metal), spatial and social environment (from where, for whom) and usage (where did it circulate, how long, what particularities) that establish relations to others. ${ }^{23}$ A third aspect of context I call arrangement which means the intentional association of things and motifs in spaces in differentiation to assemblage. ${ }^{24}$ The latter are combinations of image-objects circulating or present in a certain space, as e.g. the paintings in a room of a certain period combined with imagery of a later time and a foundation deposit in the same house from its beginnings. ${ }^{25}$ An arrangement entails material objects that show a potentially intentional relations to each other; arrangements offer clues that refer to non-present objects (a similar statue type), evoke past ones (myths that are known through many images and narratives), or

(C.E.), 2019 and Mol, 2015. For relevant criticism see recently Roskams, 2019, pp. 2-3 and 11-14; and Bräunlein, 2016 more specifically on material agency in religious studies.

23. The use of "context" differs and needs a definition from case to case. See Barrett (C.E), 2019, e.g. pp. 12-19; pp. 48-50 on contextualization: she uses "ensemble", where I use assemblage.

24. In the anglophone archaeology it means associated finds as the outcome of a process of intentionally or non-intentionally buried objects ("Vergesellschaftung"), see e.g. Joyce and Pollard, 2010. See Gosden, 2005, esp. p. 194 for a broader understanding of assemblage ("cultural assemblage") and Hamilakis and Jones, 2017, pp. 81-83 for underlining also affective relations in combinations of objects.

25. Robinson, 2002, pp. 94-98 for foundation rituals e.g. in the Caupona di Amarantus I 9. 
direct to future ones (which is the imagined deities that are addressed for future needs). Arrangements as intentional combinations of material evidence offer a possibility for further analysis in the understanding of Schatzki's "practice-arrangement-bundles" and Reckwitz's "artefact-space-structuration". ${ }^{26}$ These social theorists with a clear interest in material aspects of social relations put an emphasis on the constellations of material objects and individuals (subjects) that structure social relations and as such produce a meaningful social environment. Both the incidental and the intentional combinations (assemblage and arrangement) form the background for ascribing religious meanings to image-objects.

But when was a piece part of a religious practice? What are the archaeological criteria for singling out religion as communication? If repeated practices and habits shape religious rituals, the archaeological evidence needs to be similarly structured, appear in a repeated pattern and have a communicational character as e.g. addressed to a supranatural addressee. ${ }^{27}$ The assemblage, the non-patterned evidence allows for taking seriously the less consciously perceived connections and less intentional viewing habits of paintings, jewelry or statuettes. Arrangements, i.e. repeatedly found patterns such as statuettes in a niche of the house or beads with recurring symbols are more formalized and have signs of a directed communication (over-life size imagery; exaggerated shapes, understood as apotropaic; non-functional objects such as gilded garments, miniature vessels etc.).

If ritualization is fostered by repetition (and a creative adaptation of such repetition), this is reflected by patterns - but at the same time their disruption - in find situations and in iconographic, spatial, formal, stylistic, or material expressions. Patterns, then, also reflect habits. The creativity of human agents to adapt a set of practices and habits according to changed situations is marked by changed patterns. This approach does not only incorporate the lived aspect of religion (and also ritual) but opens a perspective on the degrees of religiousness and the assumption of "light" religious meanings. ${ }^{28}$

26. See Schatzki, 2002, pp. 59-122 and Reckwitz, 2012, pp. 251-252.

27. On recent discussion of the recognizability of ritual in archaeology and the role patterned deposits see Garrow, 2012 and Swenson, 2015. However, pattern does not only mean the repetition of a motif or a structured deposition, but its repeated occurrences as e.g. coins in bodies of water. The deposition question is more intensively dealt with in prehistoric archaeology. In Classical Archaeology it is a topic e.g. in the Italian research, cf. Gentili, 2005.

28. See nn. 5 and 11. The lingering of image-objects resp. their interpretation between decorative and meaningful that is not mutually exclusive pervades Barrett (C.E.), 2019. 
Since these interpretations are highly dependent on the three dimensions of contexts, that is, the (image-)object's characteristics as well as the arrangements it is combined with, they are often too easily applied. This approach opens a perspective on relations between the things that are not archaeologically connected to create meaning for the users.

If we look for repeated combinations of artefacts of characteristics and features pertaining to the communication with the superhuman we can start with e.g. a type of evidence repeatedly found in Pompeii: simple niches in the houses' walls, often in kitchen areas. They may house paintings and statuettes that include snakes, fruits, various deities or ancestors; some are equipped with ledges for further deposits. ${ }^{29}$ If in a marked-out place remains of small ceramic vessels and bronze objects are found in larger numbers, this accumulation points to not normal or everyday usage of these items. ${ }^{30}$ And repetition over three centuries allows us to label this practice "religious" and the place one of repeated ritualized acts. ${ }^{31}$

Patterns and arrangements allow for an approximation to religion. I argue that it is more useful to single out "practices of communication" and to look for their appearances in various social spaces. If we start from individuals as agents who learned certain strategies of communication, copied and re-shaped them for various needs in the contexts they lived in (familia, the urban quarters, their peer-group), a similar set of communicative practices takes place in different social spaces: A Pompeian could present gifts to images of the gods in a kitchen area or at a temple close to the forum. Only the numbers of participants or observers varies, but not the practice and the image-object. ${ }^{32}$

29. On lararia and religion of the familia Boyce, 1937; on the paintings Fröhlich, 1991; the religion in the houses is also central to a series of studies: Krzyszowska, 2002; Bassani, 2008; Laforge, 2009.

30. At the sanctuary of ex-Fondo Iozzino, for example, see Lippolis and Osanna, 2017; Osanna and Pellegrino, 2017.

31. Starting from practice-oriented and relational approach in the various socio-spatial contexts helps to overcome the opposition of private and public in archaeology, see Wallace-Hadrill, 1994 for starting the discussion of these modern terms applied to ancient evidence; see also Pirson, 1999 and Berry, 2016. For practice theory in history and archaeology see Cipolla, 2014. See n. 16 on Schatzki, 2002 and Reckwitz, 2012; see also Pauketat, 2001, esp. p. 80, on how practices and dispositions, traditions, ritual and change are interrelated.

32. Rüpke, 2020, p. 212 arguing against e.g. Laforge, 2009.

ARYS, 18, 2020 [51-94] ISSN 1575-166x 


\section{From Notes to a Chord. From the Archaeological Evidence to Patterns and a Spectrum of Religiousness}

If we need to look for repeated patterns in the material evidence to recognize religious aspects, we face the problem of the variability of the archaeological material that is systematized in material categories..$^{33}$ Patterned repetition does not stop at the limits of a material category such as statuary, paintings or coins, even though we have to take account of their own logic. It can rather be compared to similar patterns in e.g. iconography or usage.

To investigate assemblages and arrangements on the three levels of contexts I focus on two motifs of image-objects - a dwarf and a nude man - and look for their relations to viewers, users, spaces and other image-objects at the find spot, in the building complex or on the level of iconography, motif and material. ${ }^{34}$ The imageobjects and their motifs carry general connotations and resemblances but also contextually defined meanings that differ widely. How and where Pompeians saw such imagery or interacted with image-objects influences what they connected with those things. An image of a deity on a coin, in a wall painting or at the end of a visual axis in a building provides a series of possible impact options, starting with visibility, effects of size, color but also of recipients, frequency and intentionality of contact.

Settings and frames for communication - such as pit, niche, courtyard, various visual triggers such as dressed, naked, dark, grimace, and material networks traceable through various media and objects - allow for shifting meaning from an image of a deity to a ritualized communication with her or him.

\subsection{What Makes a Dwarf a Religious Figure? From Coin Imagery to an Appreciated Helping Amulet}

A dwarf-like figure appears in various materials, forms and media in Pompeii: A rather well-fed short male being squats, with the knees bent to the sides. His wideeyed face is a grimace, the mouth is open - sometimes he even sticks out the tongue. There are statuettes representing the dwarf, some looking more "Egyptian" due to the turquoise faïence; others are made from unpainted terracotta. ${ }^{35} \mathrm{He}$ appears on coins,

33. See Allison, 2004 for a comprehensive study of households and material evidence, see also the first in these area of studies: Berry, 1997.

34. Barrett (C.E.), 2019; Jashemski, 1979; Rieger (forthcoming a).

35. See Barrett (C.E), 2019, esp. pp. 258-270 on the various glazes and their meanings. With the Egyptianizing imagery I refer for my argument to the same material. However, her main focus lies on 
in wall-paintings and as beads. All show, with variations in details, a squatting person, with a belly and grimace on his face. He is often paralleled with Bes, a daemon in the Egyptian pantheon (Figs. 1 and 2) ${ }^{36} \mathrm{He}$ and his relative Pataikos ${ }^{37}$ were the subject of relevant studies on Egyptianizing material in Roman society, which discusses and relativizes his "Egyptianness" embedding this phenomenon into different nets of meaning such as otherness, identities, empire, globalization - a foreign imagery adapted to Roman contexts. ${ }^{38}$

An Egyptianizing element in the depiction of the dwarf should not be minimized, but it is rather restricted to the often applied turquoise color (Fig. 1a-b) or the arrangement of his image among other Egyptian deities in the Iseum in Pompeii or on sistra - the rattles used in the cult of Isis. ${ }^{39}$ My emphasis lies rather on the fact that he appears in various media, as statuette in gardens, on the sistra, on coins, and as beads of jewelry worn by the Pompeians. To assign him religious meaning is motivated by the image in the temple and on the sistra. Yet, the question remains how far the other media impact when and how the dwarf works as a superhuman addressee.

Grimacing dwarf images are recognizable in all mentioned media and appearances. However, his iconography differs in that he does e.g. not squat, but sits on a stool in the Iseum painting on the west wall of the room adjoining the courtyard of the temple (the so-called sacrarium). Even though this painting of the dwarf is in a temple complex, there are no signs of rituals that relate to him. The closest relation to cultic practice is in relation to the niche in the same wall of the painting of the enthroned dwarf ${ }^{40}$ which could count as belonging to the set of image-objects that increased the Egyptianizing aspects of the area as does the head of, assumedly, a Bes-statuette. ${ }^{41} \mathrm{He}$ rather plays a role in the rituals connected with Isis (and Serapis),

explaining how Roman society may have understood these images, representing a foreign part of a globalized world, including the discussion of decorative vs. meaningful. Religious aspects play a role in her ch. 6 on Isiac imagery.

36. On the names and identifications of the dwarfs see Mol, 2015; Barrett (C.E.), 2019, pp. 74-99 on the history and development of the figure of Bes.

37. Barrett (C.E.), 2019, pp. 94-99. He looks less frantic, has a bald head, does not squat.

38. Versluys, 2002; Mol, 2013 and 2015; Versluys, 2017; Barrett (C.E.), 2019.

39. Hoffmann, 1993, pp. 101-106; Moormann, 2007; see also Stannard, 2013, Fig. 1.

40. MANN, Archivio Rami, no. 00351779, incision by Giovanni Battisti Casanova, see Catalogo Generale dei Beni Culturali Codice ICCD 1500351779 (http://www.catalogo.beniculturali.it/sigecSSU_ FE/dettaglioScheda.action?keycode=ICCD3729460) retrieved 13th September 2020.

41. Fiorelli, $1860-1864$, I, p. 183 , year $1765,24^{\text {th }}$ December in the temple precinct of Isis, $13 \mathrm{~cm}$ (half life-size): "trovata una testa di uomo vecchio con baffi tutti ricci e barba stesa, (...) la quale oltre al loto 
since he is represented as involved in the ritual by shaking the sistra. ${ }^{42}$ However, it is again not him being the addressee of the communication, but a medium of the communicative act - he has a lower degree of religiousness.

If we look for the earliest appearance of the squatting dwarf in Pompeii, it is most likely that he came to Pompeii via Punic coins. What did a Pompeian in the $1^{\text {st }}$ cent. $\mathrm{BCE}$ and the $1^{\text {st }}$ cent. CE see in the dwarf? Is there a religious value to this demon or semi-god on a coin? Where he appears on coins, it is only on the so-called pseudo-Ebusi (Fig. 2a-b), not Roman coins. Ebusi were introduced to Pompeii from the Punic harbors of the western Mediterranean to Campania in the $3^{\text {rd }}$ and $2^{\text {nd }}$ cent. BCE. An imitation was then minted in the Campanian city and some other places in the $2^{\text {nd }}$ and $1^{\text {st }}$ cent. BCE, being in circulation until the early Principate. ${ }^{43}$

That these coins were imitated points to a certain reputation of these coins. This might be related to a habitual connection of the dwarf-image Ebusus with wealth, prosperity and luck. They still circulated - even though in diminishing amounts - at the time of the eruption of Mt. Vesuvius. ${ }^{44}$ Through the coins the image of the dwarf was ascribed a positive meaning by users and beholders, connected to financial liquidity, and having an apotropaic function due to his appearance. ${ }^{45} \mathrm{It}$ is an ascription and knowledge obtained from experience and habit. Any resemblance of this coin image with the Egyptianizing dwarfs is secondary to his mere association with material well-being and money in the pockets of the Pompeians. Any religious meaning of the dwarf on the coin is subdued; however, it meant something to the Pompeians because they imitated it.

If we move to another context where the dwarf appears, the connection to a religious meaning is evident and related to the positive ascriptions on the imitated dwarf. Some of the necklaces found in Pompeii contain beads representing the dwarf in combination with various other motifs of prosperity, fertility, luck, apotropaic symbols etc. (Fig. 3). One necklace was found in V 3, 11 (Fig. 3a), consisting of various beads, among them the dwarf and Egyptian deities (Harpocrates and a cat/Bastet). Another necklace with beads depicting the dwarf, Isis-Fortuna,

tiene in testa il velo in forma di cappuccio, con le code che le cadono sulle spalle, solito a portarsi dalle divinità egizie". Cf. Barrett (C.E.), 2019, p. 254.

42. For example, the sistrum found in VII 4, 13, De Caro, 2006, no. III.1. See Barrett (C.E.), 2019, pp. 321-322 for the sistra and Bes. Sistra are dealt with by Mol, 2015, nos. 149, 150, and 156 of the database, and were found in Casa di C. Vibius Italus (VII 2,18) and a shop (VII 4, 13). There is another shop were three more sistra were attested, see Manera and Mazza, 2001, pp. 61-63, nos. 18, 19, and 21.

43. For the Ebusi, the distribution of the Pseudo-Ebusi and the chronology see Frey-Kupper and Stannard, 2010; Hobbs, 2017.

44. Arévalo et al., 2013, pp. 247-248; Ribera Lacomba and Salavert Leon, 2014, pp. 195-197 and 201.

45. On the apotropaic meaning of the dwarfs Clarke, 2007. 
Harpocrates, and a lotus flower probably belonged to someone living in I 10, $7 .^{46}$ Since the necklaces are personal objects that were likely to be worn on their bodies, the function of some of the beads as amulets on the level of "personal religion" can be assumed. ${ }^{47}$ The apotropaic function and ability of the tiny image-objects playing a role in a religious setting is attested by a recent find of a set of religiously agentive objects in a box - presumably by someone offering services of soothsaying, binding spells and curses in Regio V (Fig. 3b). ${ }^{48}$

There is no ritual that we can grasp, but a piece of jewellery worn around the neck or wrist, on the finger or in the ears, was touched, viewed, and in direct contact with the body of the person repeatedly. The habitual act of haptically referring to and relying on the image-objects on the body is part of an embodied knowledge about their agency. Hence, a religious meaning, not on a high "amplitude" because of the low complexity and small number of interrelated agents in this practice (an individual's body), can be assumed for these pieces of jewellery, or the special bead with its motif. For the wearer of a necklace, the choice of the motif, a gesture of touching it, is a more religious act than anything we could reconstruct for the image of the dwarf in the religious building of the temple of Isis. Hence, the tiny dwarfs in the necklaces are more religious, if we locate them in the "spectrum of religiousness", than his image in the temple. He is the addressee of religious communication and repeatedly arranged and intentionally integrated in the necklaces.

Recent studies on the find contexts of the dwarf statuettes reveal that most of the images were not found in houses, but in gardens and yards in Pompeii (Fig. 1c-d). ${ }^{49}$ Thus the dwarf is rather connected to nature (even though a tamed one in the highly organized small gardens of Pompeian houses) and the paintings of nature, the fountains, and other pieces of decoration than to e.g. lararia. What

46. One necklace was found in a box which also contained statuettes of Harpocrates and of Venus Anadyomene, see Boyce, 1937, p. 108, no. 2; for the one from I 10 see Mol, 2015, database no. 102, and NSc 1934, pp. 278-308, esp. 301-302 (Elia). See Barrett (C.E.), 2019, pp. 321-322 for amulets in Pompeii; single finds are listed in De Caro, 2006, nos. III.88-95.

47. That people differentiated between personal accessories with image-objects of religious meaning, and those without or less show the many pieces of gold- and silversmith work from Pompeii and Herculaneum, cf. D'Ambrosio, 1997. Ascription of meaning is always possible due to individual experience and memories. But imagery such as gods, phalli, dwarfs had a society-wide accepted meaning; see on amulets Dasen, 2018; Wilburn, 2018; Gordon, 2019.

48. Found in 2019 in the Casa del Giardino (V 3), see http://pompeiisites.org/comunicato-stampa/ la-fortuna-e-la-protezione-contro-la-malasorte-nei-monili-della-regio-v/ retrieved 6 January 2020 (retrieved $2^{\text {nd }}$ January 2020).

49. This was shown by Mol, 2015, fig. 4.2 and Barrett (C.E.), 2019. 
he stands for is the richness of nature and the negotiation of otherness to support establishing group belonging and identity..$^{50}$ This does not have first-hand religious significance. However, if there are turquoise statuettes, referring to Egyptian faience, the image-object of the dwarf may have worked along imaginative alleys of these assemblages that include the faraway, strange, but fascinating, Egyptian world and religion. Or just nature and its creatures.

From these patterns - dwarfs dwell in open areas and gardens, are depicted on money or worn on the body -, we can infer a shared understanding and shared habits. The dwarf figures are ascribed values of prosperity and luck and follow the iconographic pattern of bodily exaggerations and ugliness for obtaining the opposite. The dwarf pendant worn on the body is the only case where a high degree of religiousness is manifest in a practice, since people wore it on the body. The wall-painting of the dwarf in the Egyptianizing context of the Iseum in Pompeii on the other hand has the least religious role, complementing the standardized atmosphere of otherness evoked in the entire complex. ${ }^{51}$ Only the statuette of Bes found in the Iseum might have been a dedication that people could connect with the images in their necklaces. ${ }^{52}$

The dwarf was not worshipped in the sense of practices of offerings and sacrifices, neither in Pompeii nor elsewhere in Italy. His religious meaning and role in religious practices (communication with the superhuman) is not manifest in any building in the city, but rather appears in necklaces and amulets, influenced, as I argued, by his image on coins. The promise of prosperity and luck might derive from the coin imagery, whereas the apotropaic character is based on the deformation and the counter-image to human beings. ${ }^{53}$ In the pieces worn on the body, the dwarf-beads combined with other amulets were an addressee in the religious communication. It is the context of usage, the patterns of his appearance, and the relations of communication (beholders, users) that unfolds the meaning of his image-object and its grades of religiousness.

50. Barrett (C.E.), 2019, pp. 337-349.

51. I do not refer to dwarfs as such - i.e. I exclude the pygmies in the Nilotic scenes, since they are active, and do not squat or sit. See Moormann, 2007, pp. 152-153.

52. Fiorelli, 1860-1864, I, pp. 190-192: 1766, $19^{\text {th }}$ July.

53. In the garden contexts, he transports less the positive and protecting aspect than the otherness and its incorporation in Roman discourses, see Barrett (C.E.), 2019, pp. 331-352. 


\subsection{Can the Statue of a Nude Man Become Divine?}

The opposite of the dwarf in terms of ideals of beauty are representations of a idealized nude male bodies. The motif of the nude, youthful or adult man can be found in wall paintings, as statuettes, or in life- or over-life-size statues, sometimes with a spear, a sword, a helmet or adjusted to functional applications such as a carrier of lamps or trays in Pompeian houses (Figs. 4-6).

The Romans borrowed these idealized statues, embodying male virtues, from Greek art, where the gods or semi-gods such as Ares or Herakles, or the heroes from mythological accounts were depicted in this way. ${ }^{54}$ Nudity, labelled as "ideal" or "heroic" by art historians and archaeologists, is in Roman imagery the representation par excellence for a variety of ascribed meanings in the re-adaptations (copies, imitations, newly assembled statuary), from an admiring reference to Greek culture to beauty as a value per se, from conquering imagery to the symbols of recreation from the $2^{\text {nd }}$ cent. BCE onwards. ${ }^{55}$ The opposite of positive ascriptions is also possible and preserved. In the same visual scheme, the naked body can represent disgust and derision - a person and body deprived not only of clothes, but of any social status. The aptness of the nude body to work as signifier ranges from morally problematic when appearing in public, social life, to noble and morally good when appearing in statuary. ${ }^{56}$

Examples of such nude male bodies from Pompeii can be seen in various mural paintings, as for example Theseus in the Casa di Gavius Rufus (VII 2, 16-17) or Mars in the Casa del Venere (II 3, 3) (Fig. 4a). In statuary, they were visible in the Casa del Citarista (I 4, 5-6), the Casa dell' Efebo (I 7, 11-12) (Fig. 5a) or the "Palaestra sannitica" (VIII 7, 29) (Fig. 6a), whereas in statuettes, often found in the lararia, a nude man is not very common: A statuette of Helios, wearing nothing except a radiated crown stems from the lararium in the Villa Rustica di Fondo Acunzo at Boscoreale (Fig. 5c). ${ }^{57}$ In a painted niche in VII 9, 33, we see Mars at the side of Venus with altars

54. See Hallett, 2005 with an excellent study on nudity in Roman portrait statuary, however with helpful insights in the idealized statuary, too.

55. The view on what Roman statues are made for and what relation they have to the earlier imageobjects changed from the 1970s onwards, in the last 25 years the discussion of what copies are and mean started with e.g. Elsner, 1995 and 2006; see Perry, 2005, pp. 90-96 on emulation; on the relation and re-interpretation of Greek artworks see Squire, 2012. On emulation in the context of Egyptianizing imagery see Barrett (C.E.), 2019, p. 46.

56. Another strategy is caricature and over-drawing. See also Ewald, 2008 on the pivotal role of the body and their social role in Roman society of the Imperial period, and Hölscher, 2014, pp. 679-683.

57. Boyce, 1937, p. 100, no. 500B; Kaufmann-Heinimann, 1998. Today in The Walters Art Museum, Baltimore. Inv. no. 54.2290. For an image showing more of the setting with all statuettes see NSc 1921, p. 440 , fig. 11 . 
painted in front of them (Fig. 4b).$^{58}$ Mars has a chlamys over his left arm, a helmet on his head and a sword hanging by his side. ${ }^{59}$

The statuettes or paintings from the lararia have a clear religious character in so far as the household gods were the addressees of worship in the familia. But what about a probable religious meaning of the image-objects of standing nude men in a classicizing stance? The many meanings that Pompeians in the $1^{\text {st }}$ cent. CE ascribed to these images may also have included a religious one when we embed them into the assembled context of the urban fabric as the horizon of experiences of a Pompeian for making religious sense of the image-objects.

Because of the omnipresence of imagery depicting nude men with weapons in active poses as gladiators or calmly standing or bow-shooting as the deities Apollo (without helmet) and Mars the recognition of an image-object as religious works via the arrangement, but can be fostered by assemblages. Mars in the Casa del Venere is painted as a statue standing in a painted garden. The god is recognizable by his weapons and the combination with Venus but with no sign of a ritual attached. ${ }^{60}$ Even though the images were not seen as communicative agents by Pompeians, the imagery directed the conception of Apollo or Mars and what potencies the nude male body transports; this is complemented by caricaturesque counter-images. They are the repeated pattern.

To pin down gradually changing religious meanings of the motif - the nude men - I link the findings in a house and a porticoed complex in Pompeii, the Casa dell' Efebo and the "Palaestra sannitica" (Figs. 5-6). ${ }^{61}$ The statues showing naked men can be considered regarding nuances of their meanings including religious ones.

The Casa dell'Efebo obtained its name from the bronze statue of a nude youth (ephebos) made in the $1^{\text {st }}$ cent. CE referring to Greek Classical models (Fig. 5a). He can be reconstructed as a tray-carrier and is as such a representation of the ser-

58. The lararium in the Casa del Re di Prussia VII 9, 33 belongs to the third style (from 50 CE onwards).

59. Bronze statues of Apollo and Diana stood in the precinct of Apollo, north of the Forum, excavated in part, dated to the early Principate (https://www.pompeiiinpictures.com/pompeiiinpictures/R7/7\%20 07\%2032\%20p5.htm). Mars occurs often in paintings, see e.g. Lorenz, 2008, pp. 182-186, but in mythological scenes.

60. To ask about the religious aspect of the painted Mars may appear superfluous. Yet, understanding these differentiations allows us to sharpen methodologies for cases which are less clear and to find out more about "degrees of religiousness".

61. For the first description see Maiuri, 1926; NSc 1927, pp. 3-83, esp. pp. 63-66 and fig. 9: "Basamento dell'Efebo" (Maiuri). For his relation to the Nilotic garden paintings see Barrett (C.E.), 2017.

ARYS, 18, 2020 [51-94] ISSN 1575-166X 
vants in a symposium. ${ }^{62}$ First of all, he does not have anything to do with a warrior. However, warriors appear close to him if we accept the assumption that he stood close to the garden triclinium: ${ }^{63}$ At its rear wall a painting of a hunt framed by red panels decorated with nude figures with helmet and spear resp. helmet and sword (Fig. 5b). ${ }^{64}$ They stand on bases representing statues, garlands above them point to a ritual frame - at least in the imagined or imaginative area of the image. ${ }^{65}$ Another nude warrior appears in the house in form of a statuette made from bronze (Fig. 5c). It was found in a room close to the atrium (Fig. 5e). To what context exactly it belonged or were it was set up, is unknown. The warrior is shown in a more active posture than the painted warrior. He seems to swing a sword with his right hand in a forward lunge with the left leg. Such statuettes are not very common in Pompeii, and depict men clearly working as gladiators. However, they are dressed and armour-clad, and more often made from terracotta than from bronze. ${ }^{66}$ The warrior statuette was thus unlikely to be part of the bronze statuettes of a lararium and the cult of the familia. Yet, in his image-object nudeness is related to activity and bodily abilities. ${ }^{67}$

The nakedness as part of the convivium continues to be depicted in the bronze statuettes of older men with deformed bodies - it seems - due to their work of carrying tablets: The older men are all naked, have grotesques body shapes, take queer positions, and gestures (Fig. 5d). We can assume an iconographical interplay in the Casa dell' Efebo between the ephebe par excellence, Ganymede, who served wine to the gods, and the reverted imagery of the grotesque tray-bearers, ${ }^{68}$ who evoked deri-

62. See Mattusch, 2017 and Bielfeldt, 2018. Maiuri, 1926 with the supports for the tray in Figs. 6-7 (here still explained as lamp-holding extensions). It is today in the MANN Inv. no. 143753. The statue of a youth found nearby in the Casa del Citarista could be also a tray- or lamp-holder in the guise of an Apollo, see Mattusch, 2017. Statuette of a naked boy in a similar posture was found I 17, 1, see Sodo, 1991, fig. 17.

63. See supra n. 62.

64. The Casa dell'Efebo is decorated in the fourth style (after the earthquake of $62 \mathrm{CE}$ ).

65. Garlands are part of religious scenes e.g. in the painting of the Officina di Verecundus (IX 7, 5), or the huge second style garland in the Villa of P. Fannius Synistor at Boscoreale with a cist and snake alluding to religious rituals. On altars or in the friezes of temples they reflect equipment for religious practices.

66. Cf. the Hoplomachus found in the Casa di Fabius Rufus (VII 16, 22), made from terracotta, see Jacobelli, 2003, pp. 102-103.

67. Ewald, 2008 on the increasing interest in the body in Imperial times.

68. Barrett (C.E.), 2017 interprets them as representation of "envy", Maiuri in NSc 1927, p. 66 as street vendors. Playing with contradictions is also the image of the Priapus in the body of athlete from the Casa di Vettii, see https://www.pompeiiinpictures.com/pompeiiinpictures/R6/6\%2015\%2001\%20 entrance\%20p9.htm. 
sion and had an apotropaic aspect. This is a more refracted, but still a visual trigger, since the tray-bearers and the beautiful ephebe belonged to the iconographical and functional kit of the convivium; they might have evoked a mythological narrative and instantiated discussion or reflections on the gods (Fig. 5b). The painted image of the warriors or Martes in the back of the triclinium belong to the realm of mythological stories, however their depiction as statues with garlands above add up to reflection of religious practice in the image. ${ }^{69}$ These are the only faint clues hinting at a religious reading of the image-objects, not at any religious practice happening in the garden of the Casa dell' Efebo. ${ }^{70}$ However, what is clear is that a variegated assemblage of naked statue or statuettes were circulated and visible in the house.

What, though, do the naked male bodies in this assemblage mean for or in a religious communication? What do the nude, beautiful, or in the case of the small statuettes "reversed beautiful" male bodies have to do with religion? This idealized iconography was used for the depiction of humans as well as of anthropomorphic deities. In the garden and rooms of the Casa dell' Efebo nudity is presented in its variety of meanings and connotations. It is a visual trigger par excellence of someone who is good and capable in every regard - or to show the confirming opposite. "Heroic nudity" was also "divine nudity" and a common imagery (and imaginary) for many people living within the Roman Empire. ${ }^{71}$ This was part of the viewing habits, but rarely connected to religious practices.

In an adult version, statues of naked men could also stand in public places. There is no example preserved from Pompeii, but from Herculaneum: M. Nonius Balbus, one of the most important citizens in Augustan times, appears in various statue bodies in the city; one of them shows him naked, recognizable by portrait and inscription and using the body of a Greek Classical statue. ${ }^{72}$ The nude body is taken as a signifier for "capability". The dressed body transports rather "sociability"; those statue bodies that do not represent any religious act, obtain a connection with a religious meaning by the resemblance to the depictions of gods or heroes. This fluid interpretation of

69. Bielfeldt, 2018, p. 435 ascertains a religious aura of the statue remains unclear about how this is created: "What they certainly evoke, however, is the ideal context of the Greek sacred sphere". In n. 43 she refers to "the sanctity" referring to an arula found with the statue in the atrium, however in "circostanze in tutto provisorie", Maiuri, 1926, p. 337. See above n. 65 on garlands.

70. More associations of nudity are also evoked by imagery: sexual intercourse, pygmies or painted mythological scenes, as well as the panesque figures made from marble in the garden.

71. See Hallett, 2005, esp. pp. 1-19, discussing also the positions by Himmelmann and Hölscher.

72. Fejfer, 2008, pp. 218-226: nude male statue with a portrait from the early Augustan period (MANN, Inv. no. 6102). The Greek original serving as model for the ideal body of Nonius is the Diomedes by Kresilas. 
the nude man between human, derisively depicted human, heroic and divine agents is rather typical for the time of the early Principate, where the divinization of the human emperor started. ${ }^{73}$ In Augustan Pompeii a person of comparable position was M. Lucretius Decidianius Rufus, of whom three dedications were found belonging to the "Palaestra sannitica" and the Foro Triangolare. ${ }^{74}$

The overlap of meanings between divine and human bodies had to be sorted out by those seeing a statue of a naked man. The statues showing boys were not a phenomenon singular to Pompeii, though mostly standing in houses. ${ }^{75}$ The visual habit connects the nude male body with a particular (social) position (either a strong, athletic) or a pleasing position (as youthful companion at convivia). The assembled context with visual "anchors" in form of the image-objects of naked male bodies in the Casa dell' Efebo described above lead to a low degree of religiousness of this statue - linked to embodied values and mythological background.

The publicly displayed male bodies had a similar low degree of religiousness, so that it is again a patterned arrangement that might tell about a religious meaning. In Pompeii, the statue of a nude man, a copy of the Polykleitan Doryphoros, came to light in the excavations of a porticoed complex in Regio VIII, the so-called "Palaestra sannitica", where - with certain probability - the physical strength of the young men of the community was trained (and also celebrated). ${ }^{76}$ It is situated between the Foro Triangolare, the theatre and the temple of Isis (Fig. 6b). The first phase of the building dates to the second half of the 2 nd cent. BCE. It was re-organized in Augustan or Tiberian times, and closed off on its eastern side by the enlargement of the temple of Isis in the phase after the earthquake of $62 \mathrm{CE} .{ }^{77}$ The porticoed courtyard was cut off at the eastern end, and rooms were inserted on the western side, where the entrance to the palaestra shifted from the long wall to the Via del Tempio d' Iside to the western wall. On the southern side of the courtyard stands a tufa base with steps leading up from behind and a basement or altar made

73. Cf. the statue of the emperor Claudius in the guise of a nude spear bearer found at Herculaneum, MANN, Inv. no. 5593. On the highly experimental times of the early Principate regarding strategies of self-representation, divinization, god-like depictions form the background to what happened with the Doryphoros set up after the mid of the $1^{\text {st }}$ cent. CE in the "Palaestra sannitica", see below.

74. Pesando and Guidobaldi, 2018, pp. 63-64. From Stabiae, probably also from a peristyle complex, originates another copy of the calm standing naked man, see Pappalardo, 2002.

75. A third bronze statue of an ephebe was found at the Porta Vesuvio, see Zanker, 1974, pp. 37-38.

76. See below p. 73 with n. 89 for the danger of a circular argument when labelling the building a palaestra and arguing for the original context of the Doryphoros.

77. Briefly on the building's history in Pesando, 2000, pp. 159-175.

ARYS, 18, 2020 [51-94] ISSN 1575-166x 
from the same material in front of it (Fig. 9c) ${ }^{78}$ On the upper side of a tufa base, the plinth of a statue would fit the cavity of $14 \mathrm{~cm}$ depth (Fig. 9d-e). The statue of the man that was found here stands on his right leg, the left relaxed leg is slightly set off. In the logic of the contrapposto, the left underarm is raised to carry a spear (Fig. $6 \mathrm{a}$ and $\mathrm{b})$. It is a copy of the so-called Doryphoros after an original by Polykleitos from around $440 \mathrm{BCE}$, that can stylistically be dated to Augustan times (Fig. 6a). ${ }^{79}$

Even though the display of heroic statues - and in particular the copy of the Doryphoros - in the so-called "Palaestra sannitica", and in particular on the pedestal there, was discussed recently by Henzel and Trümper, a final solution is still out of sight, and will be briefly discussed here. ${ }^{80}$ That this statue of the standing nude was found in this building, can be inferred from the diaries of the excavators in the $18^{\text {th }}$ cent., where it is described as excavated in the "edificio con colonne" in Regio VIII close to the theatre the palaestra. ${ }^{81}$ Actually the notice that on "una piramide per il apoggio di una statua di marmo (...) e nella soglia vi è un piede quasi intiero, e qualche estremo di altro" suggest that the Doryphoros belonged to this base in the late phase of the palaestra, since the feet on the plinth turned out to match the "uomo nudo". 82

The reconstruction of the location of this statue on the base with the steps leading up and the altar in front of it, lacks final confirmation. There is the problem that the hole in the base is smaller than the plinth of the statue. ${ }^{83}$ However, the base was reworked in antiquity and the profiles were changed and/or repaired, as the entire arrangement of altar-base-stairs was also not part of the initial layout of the courtyard, but set up in the Augustan period, since the stairs cover the drainage of the courtyard. Also the altar in front of the base has shows of restoration; the back profiles are missing in the drawing in Overbeck and Mau from before 1884, so that the exisiting

78. The base as such belonged to the original plan of the courtyard because of its symmetrical position regarding the former larger dimensions, see the plan in Blanc, Eristov and Fincker, 2000, fig. 3. The stairs behind the base belong to the/a later phase.

79. Zanker, 1974, p. 8.

80. Henzel and Trümper, 2018.

81. MANN Inv. no. 6011. For the find circumstances see Fiorelli, 1860-1864, I, p. 66, 1797, 13th April: "si è trovata una statua di marmo ehe rappresenta un uomo, eon le mani rotte e le gambe mancanti. ...."; 3rd August: "Si è scoperta una piramide per appoggio. di una statua di marmo, e uella soglia vi è un piede quasi intiero, e qualche estremo di altro. Non si puo dire, se appartenesse alla statua che qui si ritiene"; 17th August: "Vi e terminato di evaeuare interamente il consaputo edifieio con colonne, e si sono trovate le due gambe mancanti alla statua, qotata nel rapporto dei 13 aprile corrente anno".

82. Avagliano, 2013.

83. The cavity measures $57 \times 53 \mathrm{~cm}$, whereas the plinth (not rectangular) measures $55 \times 66 \mathrm{~cm}$. 
ones are the result of a restoration. ${ }^{84}$ The broken and renovated profiles in the back part of the base point to changes, assumedly for making the base of the Doryphoros fit in; here the plinth of the Doryphoros is larger because of the massive strut (Fig. 6a). One can assume that the statue of the Doryphoros was set up on the base in the post-earthquake phase of the palaestra. ${ }^{85}$ Admittedly, the cavity in the base is prepared in a sloppy way that is known from other post-earthquake measures in the city. ${ }^{86}$ However, the heroic nude male statue was displayed on the base with an altar in front of it, and had stairs behind him so that e.g. a wreath could be put on his head. The little weathering of the statue, which dates to Augustan times, could also be explained by the later insertion into the base after $62 \mathrm{CE} .{ }^{87}$

The long argument about the nude statue of a man on a base with the possibility of being wreathed as a sign of a ritual practice, ${ }^{88}$ serves the purpose of testifying to the iconographical motif of nakedness allowing for heroization if not divinization, though the concrete religious meaning is only granted by the communicational act of devotion and of gift-giving. Some Pompeians could have done so putting offerings on the altar.

The spectrum of religiousness of image-objects can be tracked in acknowledging the spatial and iconographical assemblage that ranges from images that could only be looked at - the hero embedded in a narrative or the god standing on a base in the paintings - and could be treated discursively - from the reversed image of the grotesque men provoking derision, to the luxury object of a tray carrier that invoked mythological figures, to the image of the hero in the palaestra that was involved in practices in which he was the addressee. ${ }^{89}$ The motif of the nude male body ranges from the divine to non-divine (the warrior, hunter) appearing on quite different levels of meaning in the decoration of a wall, or as a luxurious instrumentum domesti-

84. Pesando, 2000, p. 156, not explaining exactly what this renovation looks like. See the image in Overbeck and Mau, 1884, after p. 151.

85. Maybe one of the dedications to M. Lucretius Decidianus (CIL X 851) was set up there before the Doryphoros, see supra p. 71 with n. 74.

86. See e.g. the preliminary building measures and work in progress on the Forum, examined by Kockel and Flecker, 2009.

87. Since the statue has stylistic traits of Augustan times, and the base seems to be prepared only after the earthquake, it was not originally made for this location. Also, the little signs of weathering of the head of the Doryphoros speak in favor of a short period in the open, spanning the ca. 15 years between the earthquake and the eruption; contra Henzel and Trümper, 2018.

88. See supra n. 66 on garlands; on wreaths in religious practices see Bergmann, 2010, pp. 5-35.

89. In the eastern parts of the Roman Empire many gymnasia were equipped with athletic statues, Henzel and Trümper, 2018. However, the conclusion that statues pertain also in the West to palaestrae is not compelling, since the authors do not consider different socio-spatial traditions in layout and use. 
cum for the convivium. Yet, the iconographical trigger of a nude male body existed and was part of viewing habits, open to be also associated with religious rituals.

\section{A Chord Played in Arpeggio. From Habits to Social Habitus, from Practices to Rituals}

What connects the two examples of the dwarf and the nude man are viewing and using habits that go beyond a recognition of the motif of "hero", "god" or "demon". The imageobjects with which beholders and users engaged were able to trigger certain connotations and meanings, since the motifs were frequent in various media, forming assemblages or being grouped in arrangements that influenced viewing habits.

Varying assemblages could affect habits: Once the statue of the nude man stood in the "Palaestra sannitica", wreathed and with an altar in front of him, he had a religious meaning that could influence the viewing habits and connected meanings. Once the Pseudo-Ebusi went out of date around the time of the earthquake and disappeared in the sinks and soil of Pompeii, the meaning of the dwarf on them could change, if he was no longer commonly visible on coins.

This approach to the image-objects, locations, and the reconstructed practices from loose assemblages to clear arrangements in Pompeii allow for further conclusions regarding religious habits, habitualization and ritualization among Pompeians. The "spectrum of religiousness" reflected in the archaeological record, habits, routines and rituals involving image-objects are the practice-oriented pendants. ${ }^{90}$

\subsection{Habits and Material Patterns and Social Habitus}

Habits are defined as the repeated embodied behavior of individuals, established by their unquestioned everyday or periodical practices. Hence, habits are always oriented along a socio-cultural frame, in which individuals live. They form their social habitus and are vice-versa shaped by social habitus in the interplay of an individual's disposition to react to contingencies of daily life or life in general and its societal conditions.

Habits as practices of individuals can leave traces in the material environment, its styles, materials, motifs, and patterning. ${ }^{91}$ In the religious life of Pompeians this is reflected in the evidence that e.g. people represented their household deities in form

90. See supra nn. 7 and 28.

91. See supra pp. 59-61. Bourdieu, 1977, p. 9 speaks of "the mind born of the world of objects". 
of statuettes, often set up in niches; that dwarfs appeared on coins, in beads, but also as statuettes in the gardens; that marble or bronze statues referred to Greek sculpture, but were re-appropriated and also adapted to a worshipped image-object. ${ }^{92}$ As analyzed in the examples, these image-objects could become religious ones by practices that are reflected by a repeated pattern in the material evidence.

Such habits are discursively constructed and re-adapted, in a spatial and historical setting: The agents - Pompeians in the $1^{\text {st }}$ cent. CE - had the experience and embodied knowledge that e.g. a dwarf in certain material appearances can have positive powers and support an individual. This meaning made only sense in Pompeii and the other cities where the coins were minted. The male bodies in their multifarious presence in image-objects carry positive values and embody literal potencies that in the Pompeian example finally qualified the statue to be an addressee of religious communication. The habit of wearing jewellery entails the possibility of wearing agentive pieces on the body - apotropaic, propitious, supporting symbols or figures. A habitual act might have been to touch or rub over it or to look at it. ${ }^{93}$ These habits, practiced by individuals, represent a way of religious communication, and were part of the discursive shaping of the socio-cultural framework. Hence, the social habitus as frame for a society's and individuals' shared values is dynamic due to the changing habits.

The Bourdieuan concept of habitus was operationalized and applied in Classical archaeology for analyzing the elites' strategies of distinction and the processes of adaption and copying by lower social strata, closely linked to semiotic interpretations of image-objects. However, what needs to be considered is a bottom-up view on habits, embodied knowledge and its relations to social habitus - from every-day practices to material habits and social habitus. ${ }^{94}$

For asking about degrees of religiousness of image-objects, the approach combining lived ancient religion and the Bourdieuan concept of habitus widened to cultural habitus helped to go beyond statements of iconographical similarities of

92. Hölscher, 2014, on "Meaning and Art Forms" draws on Bourdieu, 1979: "if the body's postures, forms of action, and ways of behavior, in 'reality' and in art, are conceived of as expressions of social 'habits', a bridge can be built to cultural theory. For bodily 'habit' or hexis is clearly, in a cultural sense, a part of the general notion of the cultural 'habitus' of societies and their subgroups, developed by Pierre Bourdieu as a fundamental concept of historical sociology" (quotes at pp. 682 and 683).

93. Frankfurter, 1998, pp. 126-127.

94. Reichardt, 2013; Schreg et al., 2013. The sociological approaches of Bourdieu were used in archaeology for analyzing social classes and their relations, strategies of distinction, power relations as well as acculturation and identity forming. See for example Wallace-Hadrill, 1994; Zanker, 1995; Hölscher, 2004 and supra n. 92. 
image-objects or semiotic interpretation messages to be received. Based in the practice-oriented understanding of habits and habitus, motifs and objects are conceived of as passe-partouts for meanings; a religious meaning - as outlined above - can be assumed if communicational aspects are fulfilled in assembled or arranged and patterned material evidence.

\subsection{Evaluating Patterned Material Evidence as Cadence of Ritualization}

The evidence reflects a range of activities - casual ones in assemblages, intentional ones in patterned arrangements -, from which we can deduce habitual practices and routinized behavior. ${ }^{95}$ Framed and informed by the socio-material environment from the habits and routines, ritualization can develop. Rituals are the form of repeated and symbolically invested and performed (religious) practices that keep the processes of a societal or individual equilibrium and the negotiations about it going. If we see such practices repeatedly in the material evidence a ritualization can be inferred from them. The religious rituals fulfill the role of communication embracing the social and material as well as an environment beyond the practitioner in order to cope with local, personal, or communal constraints, problems, and wishes. The more formalized habitual practices are and the more often they appear in the evidence, the more it is likely to be understood as ritual: If e.g. a statue receives gifts on an altar or words of a prayer are uttered touching a special bead, the representations and imageobjects obtained a religious meaning. The gaze onto the image of a ring with the image of a dwarf, a touch of a bead representing him, or the gesture towards the niche in the atrium or kitchen to household gods, when passing by, are easily performed acts and not very complex. The involved image-objects receive their "degree of religiousness" only through the habitual knowledge and social agreement of what a religious communication looks like. Such habits are repeated, embodied, learned and taught in the frame of a social habitus of how and when to communicate with the gods. Hence, the seeds for ritualized practices for the purpose of religious communication are the discursively negotiated evaluations of common imagery embedded into a social habitus: on coins they promise prosperity, in statuettes in the lararia they represent the familia, in ambivalent combinations of bronze statuary in the houses and at convivia

95. Routine is defined as a standard procedure, more strictly fulfilled on a regular set of single actions, whereas a habit is the unconsciously pursued series of actions (and routines) done regularly and defining how a routine is conducted. Michaels, 2016 explains routine regarding engaged material objects as less formalized (e.g. washing and ablution, cooking and preparing a sacrifice with food stuff). 
they blur the lines between an instrumentum domesticum, a work of art and agentive object, that offers the background for religious practices such as sacrifices conducted in different spatial environment. ${ }^{96}$ If we accept this perspective on religion, ritual and the involvement of image-objects or spaces, the material evidence can be read in a non-binary way: An image is not either religious or not, an object is not either used in a ritual context or not. Rather, it can take various positions on the spectrum of religiousness depending on the human agents. They are in turn influenced by their social status, habitus and personal habits of what they conceive of as religious.

\section{Conclusion}

The attempt to reconstruct the spectrum of religiousness of image-objects focused on the entanglement of image-objects and viewing and using habits of the Pompeians in the $1^{\text {st }}$ cent. CE who were interested in religious communication. It embraced a focus on practices and habits - embodied knowledge, repeated actions, learned traditions and standardized image-objects of high recognizability, in order to account for the dynamic and communicative aspects of material religion as part of social interaction.

In two examples of image-objects the way from habit and routine to a religious ritual were traced: The dwarf with Egyptian predecessors triggered habitually a connection to material wealth and well-being, since he was not only known from statuettes, but also from coins. He is a symbol in personal objects of support - amulets worn on the body. In the case of the statues representing nude male bodies, Pompeians connected the well-formed naked body with "good" - heroic, divine, strong - qualities, confirmed by bodies depicted in the reverse mode as grotesquely exaggerated and old. The habitual agreement and societal habitus of this image being "good" allowed for Pompeians setting up an altar for one of these statues, thus becoming a divine addressee where before it had no particular divine characteristics.

This approach sheds light on the often too undifferentiatedly assumed ubiquity of religion and ritual. The analysis of the material evidence offers a model of how methods and approaches in the archaeology of religion can be fanned out and enrich our understanding of Roman religious practices and to take into account the finetuned differences: Human agents in establishing their relations to the world around and beyond them act on the one hand upon highly recognizable features, but on the other hand upon highly variable ones. Religious communication which a Pompeian started in order to relate to the suprahuman world needed religious concepts (gods)

96. See supra pp. 57-59. 
and socio-spatial practices (offerings, prayers) to engage with material image-objects. The latter are part of everyday routines and habits (bead, statue), embedded in a social habitus. Only the practices make the difference: The ritualization, repetition, framing, purpose/addressee that give the image-object a religious meaning, are dynamic processes. By viewing habits and practices, the image-objects offer by habits of seeing and practices aspirations to religious meaning. Visual triggers in the material environment around the Pompeians as well as individual experiences add up to ascriptions of religious meanings that cover the entire range from vague religious atmosphere to curses and soothsaying to public sacrifice - different levels of religiousness. The employment of image-objects in a variety of practices covers various expressions of religion, beyond just religious or non-religious, but opening an entire spectrum of religiousness. Here lies an untapped potential in the archaeological material, since a close look at the local and situational assemblages of image-objects, their functions, involvement in practices, their accessibility, visibility and availability open the perspective on religion and ritual beyond binary oppositions. 


\section{IMAGES}
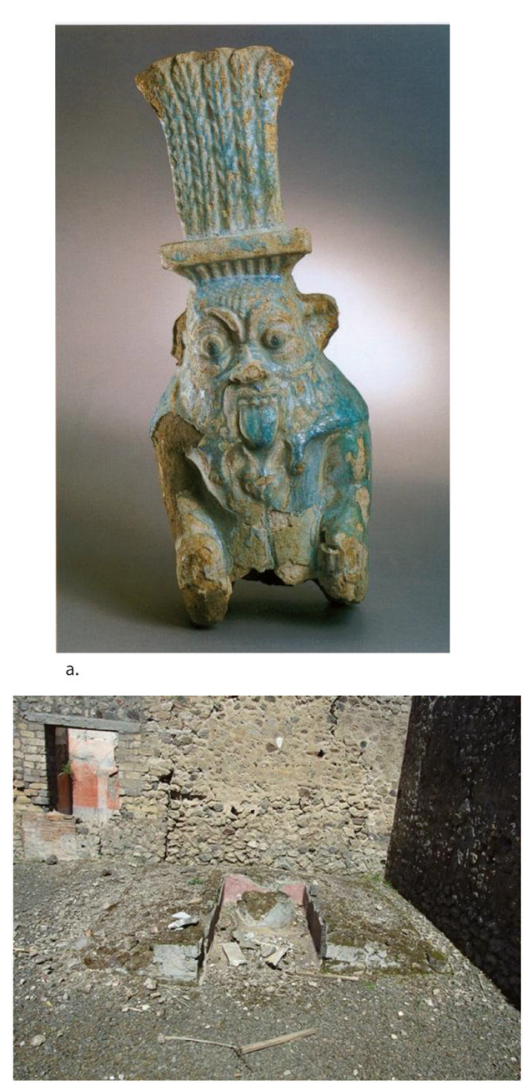

c.

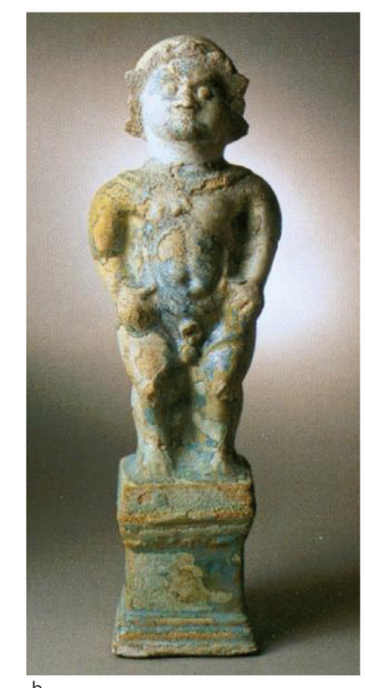

b.

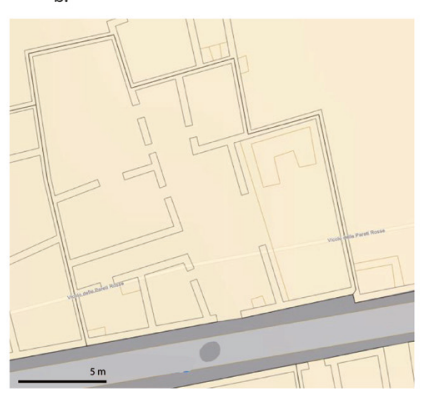

d.

Fig. 1. Dwarf figures as statuettes in gardens and yards of Pompeian houses: a. Statuette of Bes, find spot unknown, terracotta with blue-greenish glaze, ca. 34 cm, MANN Inv. no. 22583; b. Statuette of Ptah-Pataikos, from Caupona VI I, 2, terracotta with blue-greenish glaze, ca. $48 \mathrm{~cm}$, MANN Inv. no. 22607; c. Find spot of statuettes of squatting dwarfs in the garden triclinium of the Casa di Acceptus e Euhodia (VIII 5, 39) (https://www.pompeiiinpictures.com/pompeiiinpictures/R8/8\%2005\%2039_files/image019.jpg, retrieved 4 January 2020); d. Plan of the Casa di Acceptus e Euhodia (VIII 5, 39) (https://www.arcgis.com/ apps/webappviewer/index.html?id=084ee7adbe8440078311a48ad12e43cb\&extent $=1610443.8646 \% 2 \mathrm{C} 4974669.5345 \% 2 \mathrm{C} 1615030.0863 \% 2 \mathrm{C} 4976687.9498 \%$ 2C102100). 


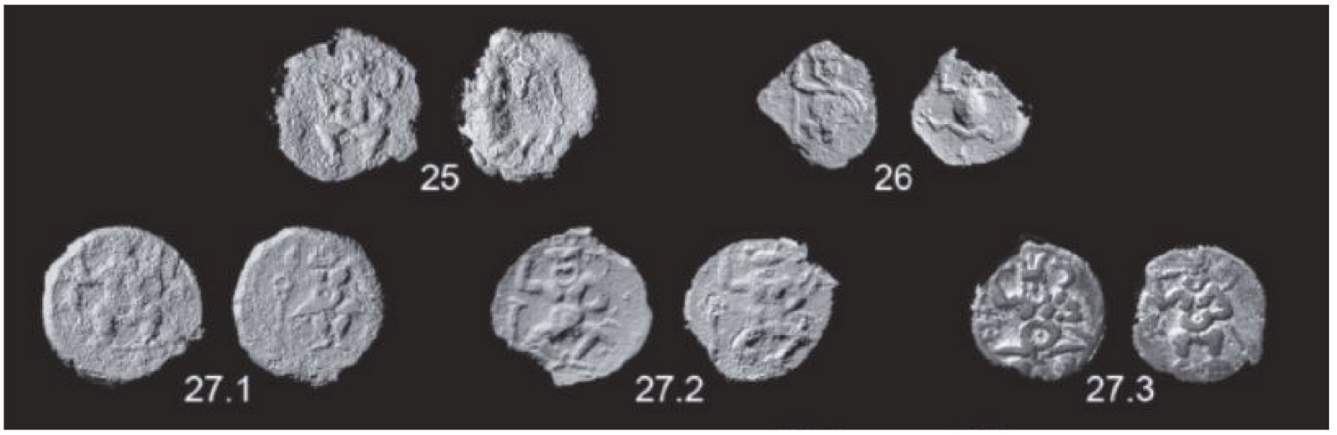

a.
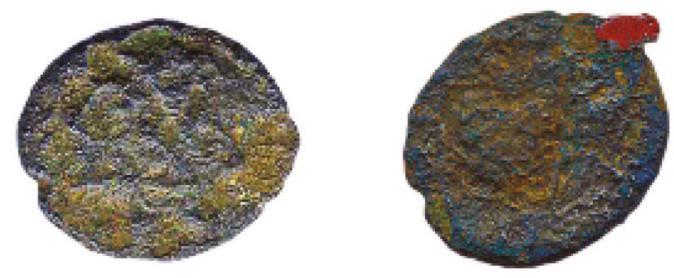

b.

Fig. 2. Dwarf figures on imitations of Punic coins (Pseudo-Ebusi) with images of the dwarf, circulating between the $2^{\text {nd }}$ cent. BCE to early $1^{\text {st }}$ cent. CE. a. Pseudo-Ebusi (Stannard, 2013, fig. 11); b. Pseudo-Ebusus from the Casa di Ariadne from a layer dated to the $1^{\text {st }}$ cent. CE (Arévalo et al., 2013, fig. 11). 


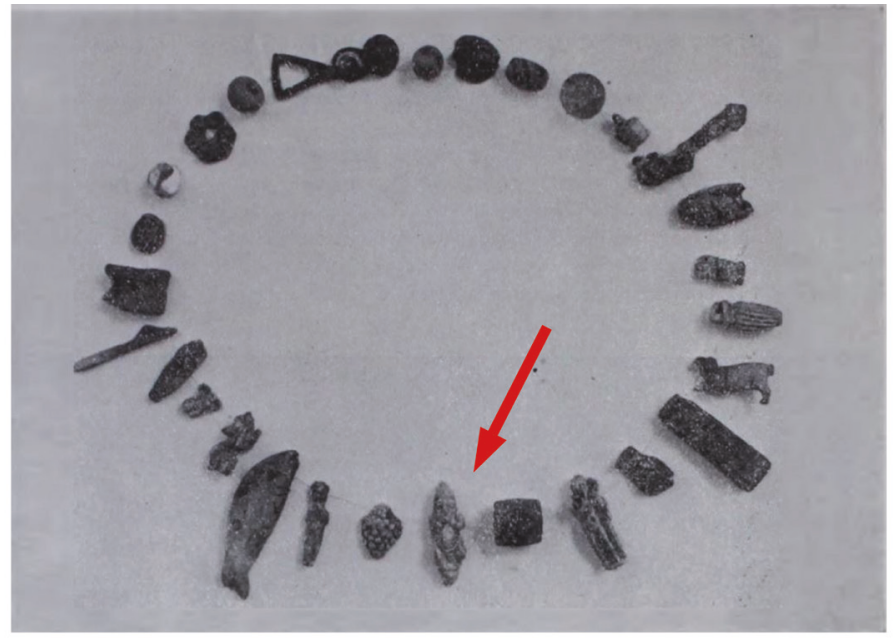

a.

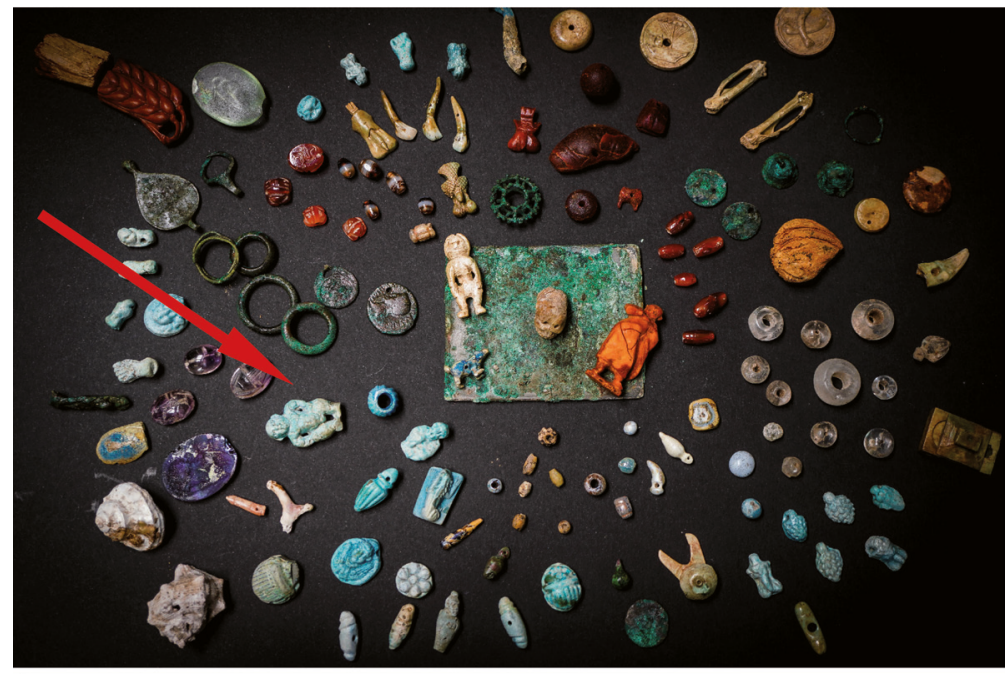

b.

Fig. 3. Dwarf figures with contact to individuals' bodies (marked by the arrows). a. Necklace with apotropaic and propitious imagery of the beads (V 3, 11) (Dyer, 1875, after p. 446). b. Set of tiny objects with apotropaic and propitious imagery and meanings for soothsaying and divination found 2019 in the Casa del Giardino (V 3). (http://pompeiisites.org/comunicato-stampa/la-fortuna-e-la-protezione-contro-la-malasorte-nei-monili-della-regio-v/ retrieved 6 January 2020, photo: Cesare Abate/ANSA). 


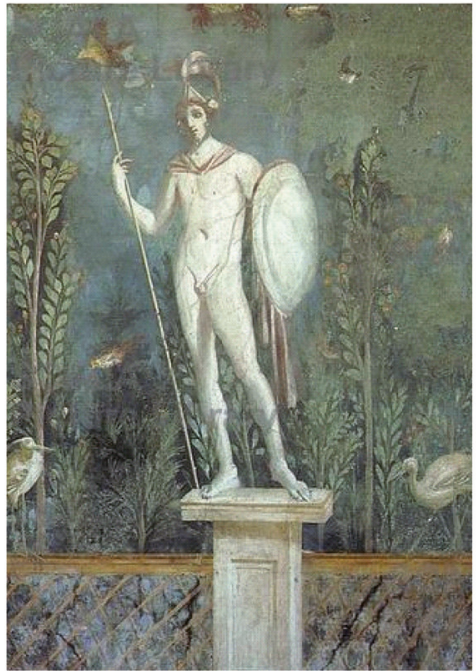

a.

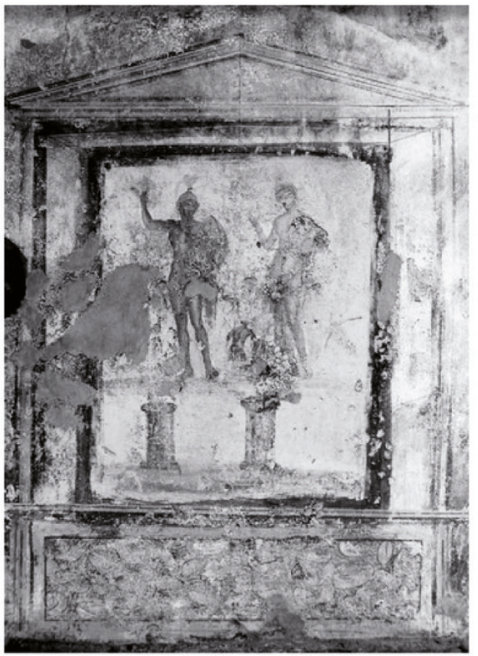

b.

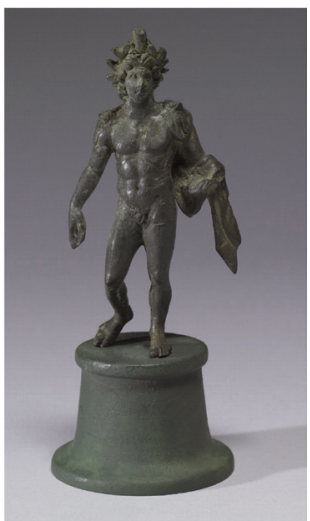

C.

Fig. 4. Nude male figures in different functions: a. Painted statue of Mars on a wall in the Casa della Venere (II 3, 3) (Scala, Florence/Luciano Romano); b. Lararium painting from the Casa del Re di Prussia (VII 9, 33) (Lorenz, 2008, fig. 56); c. Statuette of Helios, from a lararium (Fondo Acunzo) (Walters Art Gallery, Baltimore Inv. no. 54.2290). 


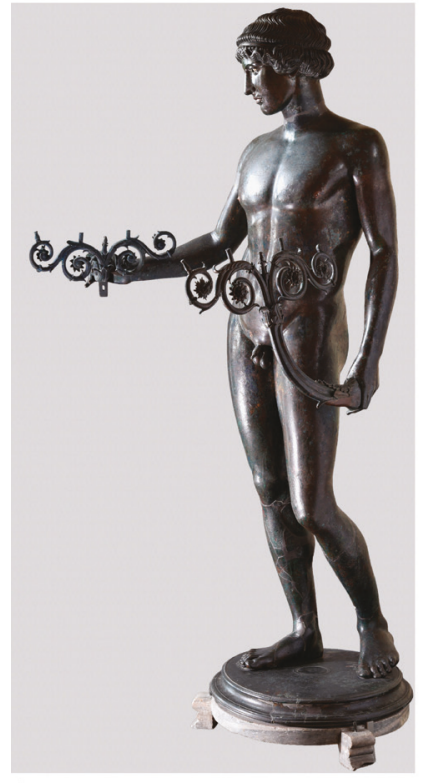

a.

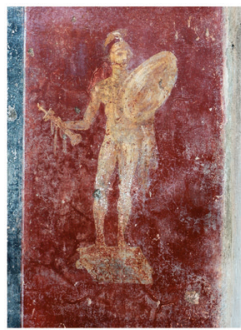

b.

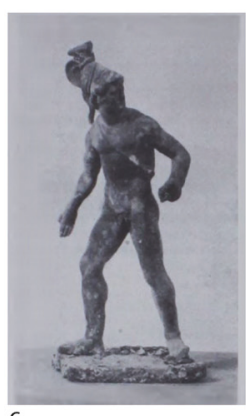

C.

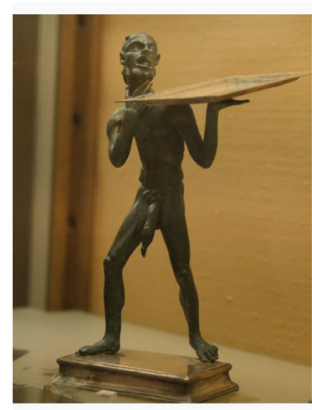

d.

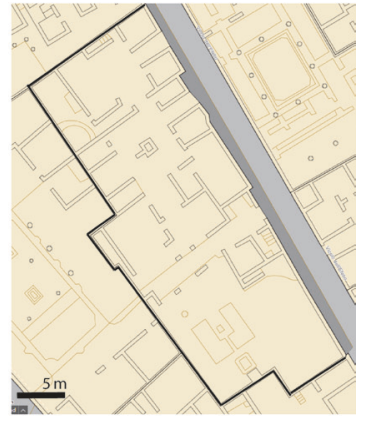

e.

Fig. 5. Image-objects of nude men from the Casa dell'Efebo: a. Bronze statue of an ephebe as tray-carrier (MANN Inv. no. 143753, Bielfeldt, 2018, fig. 8); b. Painting of a warrior on the rear wall of the garden triclinium (https://commons.wikimedia.org/wiki/File:Casa_dell\%27efebo,_cortile_con_triclinio_ all\%27aperto,_scena_di_caccia_03_guerriero.jpg); c. Statuette of a warrior from the northern parts of the house (NSc 1927, p. 68, fig. 31); d. Statuette depicting an old, deformed man, functioning as a tray-carrier, MANN, Inv. no. 143759 (Barrett [C.E.], 2017, fig. XXX); e. Plan of the Casa dell'Efebo (https://www.arcgis.com/apps/webappviewer/index.html?id=084ee7adbe8440078311a48ad12e43cb\&extent $=1610443.8646 \% 2 \mathrm{C} 4974669.5345 \% 2 \mathrm{C} 1$ 615030.0863\%2C4976687.9498\%2C102100). 

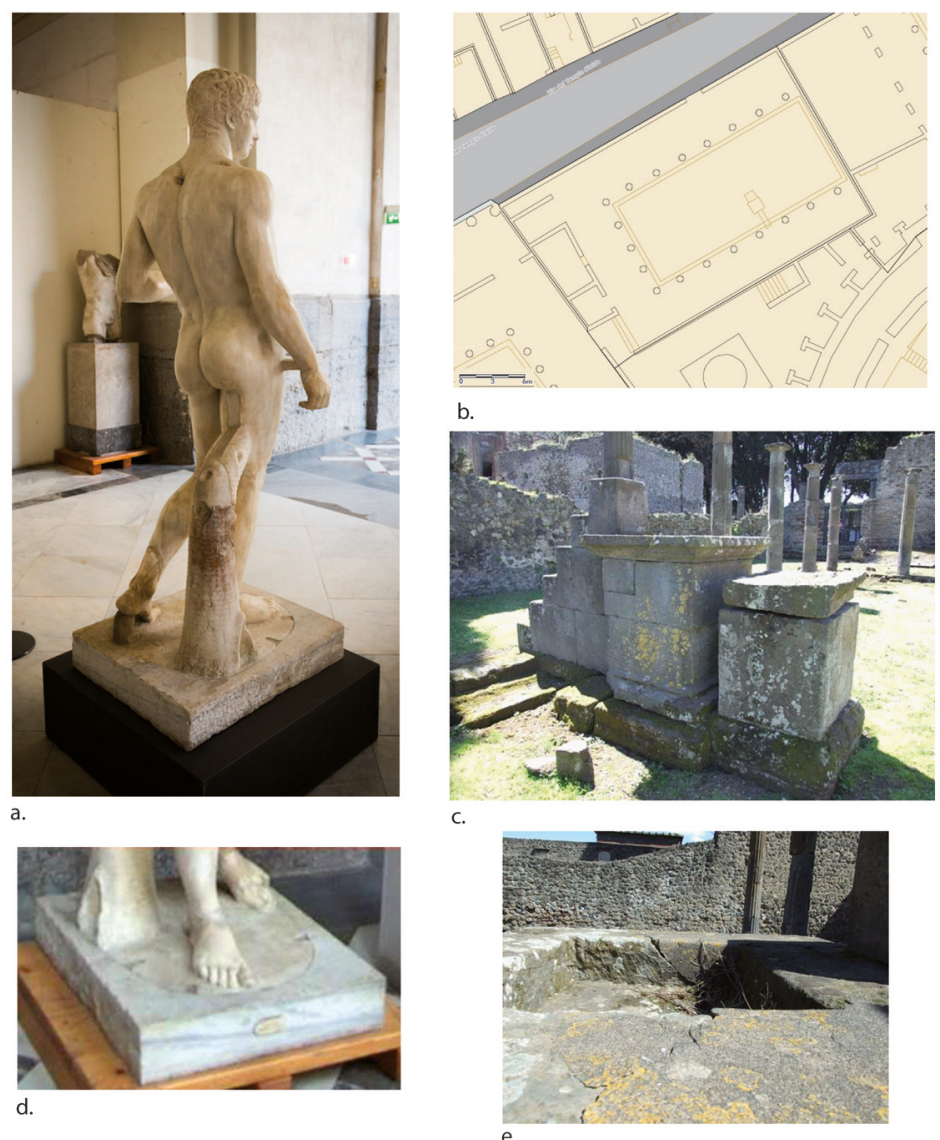

e.

Fig. 6. Image-object of a nude man from the "Palaestra sannitica" (VIII 7, 29): a. Statue of the Doryphoros, early Augustan copy of the Polykleitan statue, MANN, Inv. no. 6011 (flickr photo, James A. Glazier); b. Map of the complex between theatre, temple of Isis and Foro triangolare (https://www. arcgis.com/apps/webappviewer/index.html?id=084ee7adbe8440078311a48ad12e43cb\&extent $=1610443.8646 \% 2 \mathrm{C} 4974669.5345 \% 2 \mathrm{C} 1615030.0863 \% 2$ C4976687.9498\%2C102100); c. Base, altar and steps on the northern side of the courtyard. (https://pompeiiinpictures.com/pompeiiinpictures/R8/8\%20 07\%2029_files/image047.jpg); d. Plinth of the Doryphoros (https://pompeiiinpictures.com/pompeiiinpictures/R8/8\%2007\%2029_files/image043.jpg); e. Upper side of the base (https://pompeiiinpictures.com/pompeiiinpictures/ R8/8\%2007\%2029\%20p2_files/image005.jpg). 


\section{BibLIOGRAPHY}

Adrych, P. and Dalglish, D. (2020). Writing the Art, Archaeology and Religion of the Roman Mediterranean. In Elsner, 2020, pp. 51-80.

Albrecht, J., Degelmann, C., Gasparini, V., Gordon, R.L., Petridou, G., Raja, R., Rüpke, J., Sippel, B., Urciuoli, E.R. and Weiss, L. (2018). Religion in the Making: The Lived Ancient Religion Approach. Religion, 48.4, pp. 568-593.

Allison, P.M. (2004). Pompeian Households. An Analysis of the Material Culture. Los Angeles: University of California.

Alvar Ezquerra, J. (2018). Social Agentivity in the Eastern Mediterranean Cult of Isis. In Gasparini and Veymiers, 2018, pp. 221-247.

Antczak, K.A. and Beaudry, M.C. (2019). Assemblages of Practice. A Conceptual Framework for Exploring Human-Thing Relations in Archaeology. Archaeological Dialogues, 26.2, pp. 87-110.

Anttonen, V. (2005). Space, Body, and the Notion of Boundary. A Category-Theoretical Approach to Religion. Temenos. Nordic Journal of Comparative Religion, 41.2, https://doi. org/10.33356/temenos.4779.

Arévalo, A. et al. (2013). Nuevos ejemplos de moneda ebusitana y sus imitaciones en Pompeya: la Bottega del garum (I 12,8) y la Casa de la Regio V 4, 3. In Arévalo González, Bernal Casasola and Cottica, 2013, pp. 233-255.

Arévalo González, A., Bernal Casasola, D. and Cottica, D. (eds.) (2013). Ebusus y Pompeya, ciudades marítimas. Testimonios monetales de una relación. Cádiz: Servicio de Publicaciones de la Universidad de Cádiz.

Arnhold, M., Maier, H.O. and Rüpke, J. (eds.) (2018). Seeing the God. Image, Space Performance and Vision in the Religion of the Roman Empire. Tübingen: Mohr Siebeck.

Avagliano, A. (2013). Il ginnasio di Vibio Adriano e la vereiia. Con una nota sulla domus publica di Pompei. In Franciosi and Thémelis, 2013, pp. 65-123.

Barrett, C.E. (2016). The Archaeology of Ancient Religions. In J. Barton et al., 2016, https:// doi.org/10.1093/acrefore/9780199340378.013.48.

Barrett, C.E. (2017). Recontextualizing Nilotic Scenes. Interactive Landscapes in the Garden of the Casa dell' Efebo, Pompeii. American Journal of Archaeology, 121.2, pp. 293-332.

Barrett, C.E. (2019). Domesticating Empire. Egyptian Landscapes in Pompeian Gardens. Oxford: Oxford University Press.

Barrett, J.C. (2001). Agency, the Duality of Structure, and the Problem of the Archaeological Record. In Hodder, 2001, pp. 141-164.

Barton, J. et al. (eds.) (2016). Oxford Research Encyclopedia of Religion. Oxford and New York: Oxford University Press.

Bassani, M. (2008). Sacraria. Ambienti e piccoli edifici per il culto domestico in area vesuviana. Antenor Quaderni 9. Rome: Quasar.

Bell, C.M. (1992). Ritual Theory, Ritual Practice. Oxford: Oxford University Press. 
Bergmann, B. (2010). Der Kranz des Kaisers: Genese und Bedeutung einer römischen Insignie. Image \& Context 6. Berlin: De Gruyter.

Berry, J. (1997). Household Artefacts. Towards a Re-Interpretation of Roman Domestic Space. In Laurence, 1997, pp. 183-195.

Berry, J. (2016). Boundaries and Control in the Roman House. Journal of Roman Archaeology, 29, pp. 125-141.

Bielfeldt, R. (2018). Candelabrus and Trimalchio. Embodied Histories of Roman Lampstands and their Slaves. Art History, 41.3, pp. 420-443.

Blanc, N., Eristov, H. and Fincker, M. (2000). A fundamento restituit?: Reflections dans le temple d' Isis à Pompéi. Revue Archéologique, 2, pp. 227-309.

Böhme, G. (1995). Atmosphäre: Essays zur neuen Ästhetik. Frankfurt am Main: Suhrkamp.

Boivin, N. (2009). Grasping the Elusive and Unknowable. Material Culture in Ritual Practice. Material Religion, 5.3, pp. 266-287.

Bonifacio, G. and Sodo, A.M. (eds.) (2002). Stabiae: storia e architettura: 250. anniversario degli scavi di Stabiae 1749-1999. Studi SAP 7. Roma: L'Erma di Bretschneider.

Bourdieu, P. (1977). Outline of a Theory of Practice. Cambridge Studies in Social Anthropology 16. Cambridge: Cambridge University Press.

Bourdieu, P. (1979). La distinction. Critique sociale du jugement (Le sens commun). Paris: Éd. de Minuit.

Bowe, P. (2009). The Sacred Groves of Ancient Greece. Studies in the History of Gardens \& Designed Landscapes, 29.4, pp. 235-245.

Boyce, G.K. (1937). Corpus of the lararia of Pompeii. Memoirs of the American Academy in Rome 14. Rome: American Academy.

Brain, C.A. (2018). Venus in Pompeii. Iconography and Context. Ph.D. dissertation: University of Leicester.

Bräunlein, P.J. (2016). Thinking Religion Through Things. Method \& Theory in the Study of Religion, 28.4-5, pp. 365-399.

Bremmer, J.N. (1998). "Religion", "Ritual” and the Opposition "Sacred vs. Profane”. Notes Towards a Terminological "Genealogy”. In Graf, 1998, pp. 9-32.

Bricault, L., Versluys, M.J. and Meyboom, P.G.P. (eds.) (2007). Nile into Tiber. Egypt in the Roman world: Proceedings of the IIIrd International Conference of Isis Studies, Faculty of Archaeology (Leiden, May 11-14, 2005). Leiden and Boston: Brill.

Cipolla, C.N. (2014). Practice Theory in Archaeology. In Smith, 2014, https://doi.org/10.1007/ SpringerReference_400480.

Clarke, J.R. (2007). Three Uses of the Pygmy and the Aethiops at Pompeii. Decorating "Othering” and Warding Off Demons. In Bricault, Versluys and Meyboom, 2007, pp. 155-169.

Comella, A. and Mele, S. (eds.) (2005). Depositi votivi e culti dell' Italia antica dall'età arcaica a quella tardo-repubblicana. Atti del convegno di studi (Perugia, 1-4 giugno 2000). Bari: Edipuglia.

Daehner, J., Lapatin, K.D.S. and Spinelli, A. (eds.) (2017). Artistry in Bronze. The Greeks and their Legacy. Los Angeles: The J. Paul Getty Museum and Getty Conservation Institute. 
D’Ambrosio, A. (1997). I monili dall'area vesuviana. Studi SAP 6. Rome: L'Erma di Bretschneider.

Dasen, V. (2018). Amulets, the Body and Personal Agency. In Parker and Mckie, 2018, pp. 128-135.

De Caro, S. (ed.) (2006). Egittomania. Iside e il mistero (Napoli, Museo Archeologico Nazionale, 12 ottobre 2006 - 26 febbraio 2007). Milan: Electa.

Dickmann, J.A. (2005). Pompeji: Archäologie und Geschichte. München: C.H. Beck.

Dobres, M.A. and Robb, J.E. (eds.) (2000). Agency in Archaeology. London and New York: Routledge.

Dyer, T.H. (1875). Pompeii. Its History, Buildings, and Antiquities. An Account of the Destruction of the City, with a Full Description of the Remains, and of the Recent Excavations, and also an Itinerary for Visitors. London: Bell and sons.

Elsner, J. (1995). Art and the Roman Viewer. The Transformation of Art from the Pagan World to Christianity. Cambridge: Cambridge University Press.

Elsner, J. (2006). Classicism in Roman Art. In Porter, 2006, pp. 270-297.

Elsner, J. (2012). Material Culture and Ritual. State of the Question. In Wescoat, 2012, pp. 1-26.

Elsner, J. (ed.) (2020). Empires of Faith in Late Antiquity. Histories of Art and Religion from India to Ireland. Cambridge: Cambridge University Press.

Ewald, B.C. (2008). Review of Hallett, 2005. The Art Bulletin, 90.2, pp. 286-292.

Faraone, C.A. (2018). The Transformation of Greek Amulets in Roman Imperial Times. Philadelphia: University of Pennsylvania Press.

Fejfer, J. (2008). Roman Portraits in Context. Image \& Context 2. Berlin and New York: De Gruyter.

Fiorelli, G. (1860-1864). Pompeianarum antiquitatum historia, I-III. Napoli: Tipografia Italiana.

Fogelin, L. (2007). The Archaeology of Religious Ritual. Annual Review of Anthropology, 36, pp. 55-71.

Franciosi, V. and Thémelis, P.G. (eds.) (2013). Pompei/Messene. Il "Doriforo" e il suo contesto. Napoli: Università degli studi Suor Orsola Benincasa.

Frankfurter, D. (1998). Religion in Roman Egypt. Assimilation and Resistance. Princeton: Princeton University Press.

Frevel, C. and Hesberg, H. von (eds.) (2007). Kult und Kommunikation: Medien in Heiligtümern der Antike. Wiesbaden: Reichert.

Frey-Kupper, S. and Stannard, C. (2010). The Pseudo-Ebusus and Massalia Imitations in Central Italy. Typology and Structure, Presence in French Collections and Discoveries. Revue Numismatique, 166, pp. 109-147.

Fröhlich, Th. (1991). Lararien- und Fassadenbilder in den Vesuvstädten. Untersuchungen zur „volkstümlichen“ pompejanischen Malerei. Mainz: Von Zabern.

Fuchs, M., Linkenbach, A., Mulsow, M., Otto, B.-C., Parson, R.B. and Rüpke, J. (eds.) (2020). Religious Individualisation. Berlin and Boston: De Gruyter. 
Garrow, D. (2012). Odd Deposits and Average Practice. A Critical History of the Concept of Structured Deposition. Archaeological Dialogues, 19.2, pp. 85-115.

Gasparini, V. (2020). Renewing the Past. Rufinus' Appropriation of the Sacred Site of Panóias (Vila Real, Portugal). In Gasparini et al., 2020, pp. 319-350.

Gasparini, V., Patzelt, M., Raja, R., Rieger, A.K., Rüpke, J. and Urciuoli, E.R. (eds.) (2020). Lived Religion in the Ancient Mediterranean World: Approaching Religious Transformations from Archaeology, History and Classics. Berlin: De Gruyter.

Gasparini, V. and Veymiers, R. (eds.) (2018). Individuals and Materials in the Greco-Roman Cults of Isis. Agents, Images, and Practices. Leiden and Boston: Brill.

Gell, A. (1998). Art and Agency. An Anthropological Theory. Oxford: Clarendon Press.

Gentili, M.D. (2005). Riflessioni sul fenomeno storico dei depositi votivi di tipo etrusco-lazialecampano. In Comella and Mele, 2005, pp. 367-378.

Giddens, A. (1984). The Constitution of Society. Outline of the Theory of Structuration. Berkeley: University of California Press.

Gordon, R.L. (2019). Amulets in the Roman Empire. The Longue Durée of a Diversified Knowledge-Practice: Review of Faraone, 2018. Journal of Roman Archaeology, 32, pp. 698-703.

Gosden, C. (2005). What Do Objects Want? Journal of Archaeological Method and Theory, 12.3, pp. 193-211.

Govi, E. (ed.) (2017). La città etrusca e il sacro: santuari e istituzioni politiche. Atti del convegno (Bologna, 21-23 gennaio 2016). Bologna: Bononia University Press.

Graf, F. (ed.) (1998). Ansichten griechischer Rituale. Stuttgart and Leipzig: Teubner.

Hallett, C.H. (2005). The Roman Nude. Heroic Portrait Statuary, 200 BC-AD 300. Oxford: Oxford University Press.

Hamilakis, Y. and Jones, A.M. (2017). Archaeology and Assemblage. Cambridge Archaeological Journal, 27.1, pp. 77-84.

Hasse, J. (2008). Die Stadt als Raum der Atmosphären: Zur Differenzierung von Atmosphären und Stimmungen. Die alte Stadt. Vierteljahreszeitschrift für Stadtgeschichte, Stadtsoziologie, Denkmalpflege und Stadtentwicklung, 35.2, pp. 103-116.

Haug, A. (2014). Das Ornamentale und die Produktion von Atmosphäre. Das Beispiel der Domus Aurea. In Lipps and Maschek, 2014, pp. 219-239.

Haug, A. (2017). Stadt und Emotion. Das Beispiel Pompeji. In Kienlin and Koch, 2017, pp. 195-223.

Henzel, R. and Trümper, M. (2018). Crowded or Empty Spaces? The Statuary Decoration of the "Palaestrae" in Pompeii and Herculaneum. In Mania and Trümper, 2018, pp. 115142 .

Hesberg, H. von (2007). Votivseriationen. In Frevel and Hesberg, 2007, pp. 279-310.

Hicks, D. (ed.) (2010). The Oxford Handbook of Material Culture Studies. Oxford: Oxford University Press.

Hobbs, R. (2017). Bes, Butting Bulls, and Bars. In Wilson and Flohr, 2017, pp. 339-362.

Hodder, I. (ed.) (2001). Archaeological Theory Today. Cambridge: Polity Press. 
Hoffmann, P. (1993). Der Isis-Tempel in Pompeji. Charybdis 7. Münster: Lit.

Hölscher, T. (2004). Provokation und Transgression als politischer Habitus in der späten römischen Republik. $\operatorname{MDAI}(R), 111$, pp. 83-104.

Hölscher, T. (2014). Semiotics To Agency. In Marconi, 2014, https://doi.org/10.1093/oxfor$\mathrm{dhb} / 9780199783304.013 .030$.

Hui, A. and Schatzki, T. (eds.) (2016). The Nexus of Practices. Connections, Constellations, Practitioners. Oxford: Routledge.

Insoll, T. (ed.) (2004a). Belief in the Past. The Proceedings of the 2002 Manchester Conference on Archaeology and Religion. BAR 1212. Oxford: Archaeopress.

Insoll, T. (2004b). Are Archaeologists Afraid of Gods? Some Thoughts on Archaeology and Religion. In Insoll, 2004a, pp. 1-6.

Insoll, T. (2009). Materiality, Belief, Ritual: Archaeology and Material Religion. An Introduction. Material Religion, 5.3, pp. 260-264.

Insoll, T. (ed.) (2011a). The Oxford Handbook of the Archaeology of Ritual and Religion. Oxford: Oxford University Press.

Insoll, T. (2011b). Introduction. Ritual and Religion in Archaeological Perspective. In Insoll, 2011a, pp. 1-5.

Jacobelli, L. (2003). Gladiatori a Pompei: Protagonisti, luoghi, immagini. Rome: L’Erma di Bretschneider.

Jashemski, W.F. (1979). The Gardens of Pompeii. Herculaneum and the Villas Destroyed by Vesuvius. New Rochelle N.Y.: Caratzas Bros.

Jones, N.F. (2001). Pliny the Younger's Vesuvius Letters (6.16 and 6.20). The Classical World, 95.1, pp. 31-48.

Joyce, R.A. and Lopiparo, J. (2005). PostScript: Doing Agency in Archaeology. Journal of Archaeological Method and Theory, 12.4, pp. 365-374.

Joyce, R.A. and Pollard, J. (2010). Archaeological Assemblages and Practices of Deposition. In Hicks, 2010, pp. 291-309.

Kaufmann-Heinimann, A. (1998). Götter und Lararien aus Augusta Raurica: Herstellung Fundzusammenhänge und sakrale Funktion figürlicher Bronzen in einer römischen Stadt. Forschungen in Augst 26. Augst: Römermuseum.

Kennedy, W.M. and Eser, R.A. (eds.) (2020). Studies in Classical Archaeology. Classical Archaeology and Landscapes. Turnhout: Brepols.

Kienlin, T.L. and Koch, L.C. (2017). Emotionen. Perspektiven auf Innen und Außen. Bonn: Habelt.

Knapp, A.B. and Van Dommelen, P. (2008). Past Practices. Rethinking Individuals and Agents in Archaeology. Cambridge Archaeological Journal, 18.1, pp. 15-34.

Kockel, V. and Flecker, M. (2009). Forschungen im Südteil des Forums von Pompeji. Ein Vorbericht über die Arbeitskampagnen 2007 und 2008. MDAI(R), 114, pp. 271-303.

Krzyszowska, A. (2002). Les cultes privés à Pompéi. Acta Universitatis Wratislaviensis 2385. Wroclaw: Wydawnictwo Uniwersytetu Wroclawskiego. 
Kyriakidis, E. (ed.) (2007a). The Archaeology of Ritual. Los Angeles: University of California Los Angeles.

Kyriakidis, E. (2007b). Archaeologies of Ritual. In Kyriakidis, 2007a, pp. 289-308.

Laforge, M.-O. (2009). La religion privée à Pompéi. Naples: Centre Jean Bérard.

Latour, B. (2005). Reassembling the Social. An Introduction to Actor-Network-Theory. Oxford and New York: Oxford University Press.

Laurence, R. (ed.) (1997). Domestic Space in the Roman World. Pompeii and Beyond. Portsmouth: Journal of Roman Archaeology.

Lenger, A., Schneickert, C. and Schumacher, F. (eds.) (2013). Pierre Bourdieus Konzeption des Habitus. Wiesbaden: Springer VS.

Lippolis, E. and Osanna, M. (eds.) (2017). I Pompeiani e i loro dei. Culti, rituali e funzioni sociali a Pompei. Atti della giornata di studi (Sapienza Università di Roma, 15 febbraio 2016). Scienze dell'Antichità 22. Rome: Quasar.

Lipps, J. and Maschek, D. (2014). Antike Bauornamentik. Grenzen und Möglichkeiten ihrer Erforschung. Wiesbaden: Reichert.

Lorenz, K. (2005). Die Quadratur des Sofabildes: Pompejanische Mythenbilder als Ausgangspunkt für eine Phänomenologie antiker Wahrnehmung. In Neudecker and Zanker, 2005, pp. 205-221.

Lorenz, K. (2008). Bilder machen Räume: Mythenbilder in pompeianischen Häusern. Image \& Context 5. Berlin and New York: De Gruyter.

Lorenz, K. (2016). Ancient Mythological Images and their Interpretation. An Introduction to Iconology, Semiotics, and Image Studies in Classical Art History. Cambridge: Cambridge University Press.

Lundby, K. (ed.) (2003). Religion Across Media. From Early Antiquity to Late Modernity. New York: Peter Lang.

Maiuri, A. (1926). L'efebo di via dell'Abbondanza a Pompei. Bollettino D'Arte, 5, pp. 337-353.

Manera, F. and Mazza, C. (2001). Le collezioni egizie del Museo Nazionale Romano. Milano: Electa.

Mania, U. and Trümper, M. (eds.) (2018). Development of Gymnasia and Graeco-Roman Cityscapes. Berlin Studies of the Ancient World 58. Berlin: Topoi.

Marconi, C. (ed.) (2014). The Oxford Handbook of Greek and Roman Art and Architecture. Oxford: Oxford University Press.

Mattusch, C.C. (2017). When a Statue Is Not a Statue. In Daehner, Lapatin and Spinelli, 2017, pp. 69-76.

Meller, H. and Dickmann, J.A. (eds.) (2011). Pompeji - Nola - Herculaneum: Katastrophen am Vesuv. München: Hirmer.

Meyer, B. (2003). Material Mediations and Religious Practices of World-Making. In Lundby, 2003, pp. 1-19.

Michaels, A. (2016). Homo Ritualis. Hindu Ritual and its Significance for Ritual Theory. New York: Oxford University Press. 
Mol, E. (2013). The Perception of Egypt in Networks of Being and Becoming. A Thing Theory Approach to Egyptianising Objects in Roman Domestic Contexts. Theoretical Roman Archaeology Journal, pp. 117-131.

Mol, E. (2015). Egypt in Material and Mind. The Use and Perception of Aegyptiaca in Roman Domestic Contexts of Pompeii. Leiden: Leiden University.

Moormann, E.M. (2007). The Temple of Isis at Pompeii. In Bricault, Versluys and Meyboom, 2007, pp. 137-154.

Moser, C. and Knust, J.W. (eds.) (2017). Ritual Matters. Material Residues and Ancient Religions. Memoirs of the American Academy in Rome Supplementary volume 13. Ann Arbor, Michigan: University of Michigan Press.

Mylonopoulos, J. (2020). Materiality and Visibility of Rituals in the Ancient World. Berlin: De Gruyter.

Neudecker, R. (2015). Gardens. In Raja and Rüpke, 2015a, pp. 220-234.

Neudecker, R. and Zanker, P. (eds.) (2005). Lebenswelten: Bilder und Räume in der römischen Stadt der Kaiserzeit. Palilia 16. Wiesbaden: Reichert.

Osanna, M. and Pellegrino, C. (2017). Nuove ricerche nel santuario extra urbano di Fondo Iozzino a Pompei. In Govi, 2017, pp. 373-393.

Osborne, R. and Tanner, J. (eds.) (2007). New Interventions in Art History. Art's Agency and Art History. Malden, Mass.: Blackwell.

Overbeck, J. and Mau, A. (1884). Pompeji in seinen Gebäuden, Alterthümern und Kunstwerken. Leipzig: Engelmann.

Pappalardo, U. (2002). Una statua di Doryphoros da Stabiae. In Bonifacio and Sodo, 2002, pp. 167-169.

Parker, A. and Mckie, S. (eds.) (2018). Material Approaches to Roman Magic. Occult Objects and Supernatural Substances. Havertown: Oxbow Books Limited.

Patzelt, M. (2018). Über das Beten der Römer: Gebete im spätrepublikanischen und frühkaiserzeitlichen Rom als Ausdruck gelebter Religion. Berlin and Boston: De Gruyter.

Pauketat, T.R. (2001). Practice and History in Archaeology. Anthropological Theory, 1.1, pp. 73-98.

Perry, E. (2005). The Aesthetics of Emulation in the Visual Arts of Ancient Rome. Cambridge: Cambridge University Press.

Pesando, F. (2000). Edifici pubblici “antichi” nella Pompei augustea: il caso della Palestra Sannitica. $\operatorname{MDAI}(R), 107$, pp. 155-175.

Pesando, F. and Guidobaldi, M.P. (2018). Pompei, Oplontis, Ercolano, Stabiae. Guide archeologiche Laterza 14. Bari: Laterza.

Pirson, F. (1999). Mietwohnungen in Pompeji und Herkulaneum: Untersuchungen zur Architektur, zum Wohnen und zur Sozial- und Wirtschaftsgeschichte der Vesuvstädte. München: Pfeil.

Pollack, D., Krech, V., Müller, O. and Hero, M. (eds.) (2018). Handbuch Religionssoziologie. Wiesbaden: Springer Fachmedien Wiesbaden. 
Porter, J.I. (ed.) (2006). Classical Pasts. The Classical Traditions of Greece and Rome. Princeton, NJ: Princeton Univ. Press.

Raja, R. and Rüpke, J. (eds.) (2015a). A Companion to the Archaeology of Religion in the Ancient World. Chichester: Wiley \& Sons.

Raja, R. and Rüpke, J. (2015b). Appropriating Religion. Methodological Issues in Testing the "Lived Ancient Religion" Approach. Religion in the Roman Empire, 1.1, pp. 11-19.

Raja, R. and Weiss, L. (2015). The Role of Objects. Meanings, Situations and Interaction. Religion in the Roman Empire, 1.2, p. 137.

Raja, R. and Weiss, L. (2016). The Significance of Objects. Considerations on Agency and Context. Religion in the Roman Empire, 2.3, p. 297.

Rappaport, R.A. (1999). Ritual and Religion in the Making of Humanity. Cambridge: Cambridge Univ. Press.

Reckwitz, A. (2012). Affective Spaces. A Praxeological Outlook. Rethinking History, 16.2, pp. 241-258.

Reckwitz, A. (2016). Practices and their Affects. In Hui and Schatzki, 2016, pp. 114-125.

Reichardt, S. (2013). Bourdieus Habituskonzept in den Geschichtswissenschaften. In Lenger, Schneickert and Schumacher, 2013, pp. 307-323.

Ribera Lacomba, A. and Salavert Leon, J. (2014). La moneda en la Casa de Ariadna (VII, 4, 51-31) de Pompeya. El contexto arqueológico de las monedas de Ebusus y de las series imitativas de la pseudo-ceca de Pompeya. In Arévalo González, 2014, pp. 181-205.

Rieger, A.-K. (2016). Waste Matters. Life Cycle and Agency of Pottery Employed in Greco-Roman Sacred Spaces. Religion in the Roman Empire, 2.3, p. 307.

Rieger, A.-K. (2018). Imagining the Absent and Perceiving the Present. An Interpretation of Material Remains of Divinities from the Rock Sanctuary at Caesarea Philippi (Gaulantis). In Arnhold, Maier and Rüpke, 2018, pp. 27-58.

Rieger, A.-K- (2020). This God is Your God, this God is my God. Local Identities at Sacralized Places in Roman Syria. In Gasparini et al., 2020, pp. 351-384.

Rieger, A.-K. (forthcoming a). Pathways of Religious Experiences in the Urban Fabric of Roman Pompeii. In: Woolf and Norman (forthcoming).

Rieger, A.-K. (forthcoming b). Landscape as Artefact and as Agent. The Potentials of Landscape Archaeology in Arid landscapes for Research in Classical Archaeology. In Kennedy and Eser (forthcoming).

Robinson, M. (2002). Domestic Burnt Offerings and Sacrifices at Roman and pre-Roman Pompeii, Italy. Vegetation History and Archaeobotany, 11.1-2, pp. 93-100.

Roskams, S. (2019). The Limitation of Water Flow and the Limitations of Postmodernism. Theoretical Roman Archaeology Journal, 2.1, https://doi.org/10.16995/traj.371.

Rowan, Y.M. (ed.) (2012). Beyond Belief. The Archaeology of Rreligion and Ritual. Malden, MA: Wiley.

Rüpke, J. (2011). Lived Ancient Religion: Questioning “Cults” and "Polis Religion”. Mythos, 5, pp. 191-203. 
Rüpke, J. (2018). Theorising Religion for the Individual. In Gasparini and Veymiers, 2018, pp. 61-73.

Rüpke, J. (2020). Ritual Objects and Religious Communication in Lived Ancient Religion. Multiplying Religion. In Fuchs et al., 2020, pp. 1201-1222.

Schatzki, T.R. (2002). The Site of the Social. A Philosophical Account of the Constitution of Social Life and Change. University Park, Pa.: Pennsylvania State University Press.

Schatzki, T.R., Knorr-Cetina, K. and Savigny, E. von (eds.) (2000). The Practice Turn in Contemporary Theory. London: Routledge.

Schlette, M. and Krech, V. (2018). Sakralisierung. In Pollack et al., 2018, pp. 437-463.

Schreg, R., Zerres, J., Pantermehl, H., Wefers, S., Grunwald, L. and Gronenborn, D. (2013). Habitus - ein soziologisches Konzept in der Archäologie. Archäologische Informationen, 36, pp. 101-112.

Smith, C. (ed.) (2014). Encyclopedia of Global Archaeology. New York: Springer.

Smith T.J. and Plantzos, D. (eds.) (2012). Blackwell Companion to Ancient Greek Art. Malden, MA: Wiley-Blackwell.

Sodo, A.M. (1991). Lavori di diserbo e rinvenimenti nella Regio I, ins. 17, civ. 1. Rivista Di Studi Pompeiani, 3, pp. 240-243.

Squire, M. (2012). Greek Art Through Roman Eyes. In Smith and Plantzos, 2012, II, pp. 599620.

Stannard, C. (2013). Are Ebusan Coins at Pompeii, and the Pompeian Pseudo-mint, a Sign of Intensive Contacts with the Island of Ebusus? In Arévalo González, Bernal Casasola and Cottica, 2013, pp. 125-155.

Stewart, P. (2003). Statues in Roman Society. Representation and Response. Oxford: Oxford Univ. Press.

Stewart, P. (2007). Gell's Idols and Roman Cult. In Osborne and Tanner, 2007, pp. 158-178.

Stollberg-Rilinger, B. (2013). Rituale. Historische Einführungen 16. Frankfurt am Main: Campus.

Swenson, E. (2015). The Archaeology of Ritual. Annual Review of Anthropology, 44.1, pp. 329345.

Trimble, J. and Elsner, J. (2006). Introduction: "If you need an actual statue...” Art History, 29.2, pp. 201-212.

Van Andringa, W. (2009). Quotidien des dieux et des hommes: La vie religieuse dans les cités du Vésuve à l'époque romaine. Rome: École Française de Rome.

Versluys, M.J. (2002). Aegyptiaca Romana. Leiden and Boston: Brill.

Versluys, M.J. (2017). Exploring Aegyptiaca and their Material Agency throughout Global History. Aegyptiaca. Journal of the History of Reception of Ancient Egypt, 1, pp. 122-144.

Wallace-Hadrill, A. (1994). Houses and Society in Pompeii and Herculaneum. Princeton: Princeton University Press.

Wescoat, B.D. (ed.) (2012). Architecture of the Sacred. Space, Ritual, and Experience from Classical Greece to Byzantium. Cambridge: Cambridge University Press. 
Whitehouse, R.D. (1996). Ritual Objects. Archaeological Joke or Neglected Evidence? In Wilkins, 1996, pp. 9-30.

Wilburn, A. (2018). The Archaeology of Ritual in the Domestic Sphere. In Parker and Mckie, 2018, pp. 103-114.

Wilkins, J.B. (ed.) (1996). Approaches to the Study of Ritual. Italy and the Ancient Mediterranean. Accordia Specialist Studies on the Mediterranean 2. London: Accordia.

Wilson, A. and Flohr, M. (eds.) (2017). The Economy of Pompeii. Oxford: Oxford University Press.

Woolf, G. and Norman, C. (eds.) (forthcoming). Sanctuaries and Experience. Cambridge: Cambridge University Press.

Zanker, P. (1974). Klassizistische Statuen: Studien zur Veranderung des Kunstgeschmacks in der romischen Kaiserzeit. Mainz am Rhein: von Zabern.

Zanker, P. (1995). Pompeji: Stadtbild und Wohngeschmack. Kulturgeschichte der antiken Welt. Mainz: Verlag Philipp von Zabern. 